\title{
MÉTODOS DE EXTRAÇÃO E QUALIDADE DA FRAÇÃO LIPÍDICA
}

\section{AELSON Aloir SANTANa BRUM}

Dissertação apresentada à Escola Superior de Agricultura "Luiz de Queiroz", Universidade de São Paulo, para obtenção do título de Mestre em Ciências, Área de Concentração: Ciência e Tecnologia de Alimentos.

P I R A C I C A B A

Estado de São Paulo - Brasil

Novembro - 2004 


\title{
MÉTODOS DE EXTRAÇÃO E QUALIDADE DA FRAÇÃO LIPÍDICA
}

\author{
AELSON ALOIR SANTANA BRUM
}

Químico Industrial

Orientador: Prof ${ }^{\mathrm{a}}$. Dr ${ }^{\mathrm{a}}$. MARISA APARECIDA BISMARA REGITANO-D’ARCE

Dissertação apresentada à Escola Superior de Agricultura "Luiz de Queiroz", Universidade de São Paulo, para obtenção do título de Mestre em Ciências, Área de Concentração: Ciência e Tecnologia de Alimentos.

P I R A C I C A B A

Estado de São Paulo - Brasil

Novembro - 2004 


\section{Dados Internacionais de Catalogação na Publicação (CIP)}

DIVISÃO DE BIBLIOTECA E DOCUMENTAÇÃO - ESALQ/USP

\section{Brum, Aelson Aloir Santana}

Métodos de extração e qualidade da fração lipídica / Aelson Aloir Santana Brum. - -

Piracicaba, 2004.

$66 \mathrm{p.}$

Dissertação (Mestrado) - - Escola Superior de Agricultura Luiz de Queiroz, 2004.

Bibliografia.

1. Aveia 2. Frango 3. Lipídios - Extração 4. Qualidade dos alimentos I. Título

CDD 574.19247

"Permitida a cópia total ou parcial deste documento, desde que citada a fonte - O autor" 
"Los jóvenes... yo entre ellos... tenemos que estudiar y estudiar fuerte. Para nosotros no hay eso de que la vista me duele, que no me entra la lectura, que se me cansa, que no hay espejuelos, que tengo muchas guardias, que los niños no me dejan dormir... todas esas cuestiones, todas esas cosas que andan por ahí sueltas. Hay que estudiar de todas todas.”

Ernesto Guevara de la Serna 
Aos meus pais, José Osvaldo Dias Brum e Valkíria de Jesus Santana Brum, e minha irmã, Arlene Alair Santana Brum 


\section{AGRADECIMENTOS}

À Prof ${ }^{a}$. Dra . Marisa A. B. Regitano d'Arce, pela oportunidade de poder trabalhar e aprender com ela, pela transparência e lucidez de suas idéias e, sobretudo, por ter acreditado em mim e valorizado meu trabalho durante a realização do mestrado.

Ao Prof. Dr. Jorge Horii, que me encaminhou ao Laboratório de Óleos e Gorduras do LAN, pela cordialidade e amizade.

Aos Professores Severino Matias de Alencar e Roseli Aparecida Ferrari, pelas sugestões e críticas pertinentes ao trabalho realizado.

À Prof ${ }^{a}$. Dr ${ }^{\mathrm{a}}$. Marília Oetterer, por ser uma entusiasta da pesquisa científica e que, além de ser coordenadora do curso de pós-graduação, atua como a verdadeira Mãe de todos os alunos do programa.

Ao imprescindível suporte técnico, à generosidade e, principalmente, à amizade da funcionária Maria Fernanda de Almeida Prado.

A Tatiana Pacheco, Marielen Silva e Érika Furlan, exemplos de profissionalismo, determinação e coragem. As sábias palavras de vocês, nos momentos difíceis e incertos dessa jornada, foram determinantes no fortalecimento de nossa amizade.

A convivência pacífica e amigável com a bióloga Roberta Teresa Rizzo Benato comprovaram que ainda existem pessoas de bom humor e, sobretudo, de bom caráter.

Às minhas estagiárias Tatiane de Lima Marchesin e Talita Benedetti, alunas do curso de Ciências dos Alimentos, por terem ensinado a não me atrasar nos compromissos marcados e pela dedicação e seriedade na realização dos experimentos. 
Aos colegas e amigos que auxiliaram e estão sempre dispostos a ajudar: Ricardo Borghesi, Lia Ferraz, Juliana Galvão, Selma Pacheco, Eloíse Ribeiro, Lílian Pino, Andrea A. F. Brasil Vieira José, Hélen Figueirôa e Paulo Pagliuca.

À Cristina Saldanha, do ETH (Suíça), a grande incentivadora do meu ingresso no mundo da pesquisa e Carolina Sherrill que, apesar da distância, estiveram e estão sempre presentes.

À paciência no auxílio da análise estatística e à amizade de Juliana Di Giorgio Giannotti.

À CAPES pela concessão da bolsa de mestrado.

Aos funcionários e docentes do Departamento de Agroindústria, Alimentos e Nutrição. 


\section{SUMÁRIO}

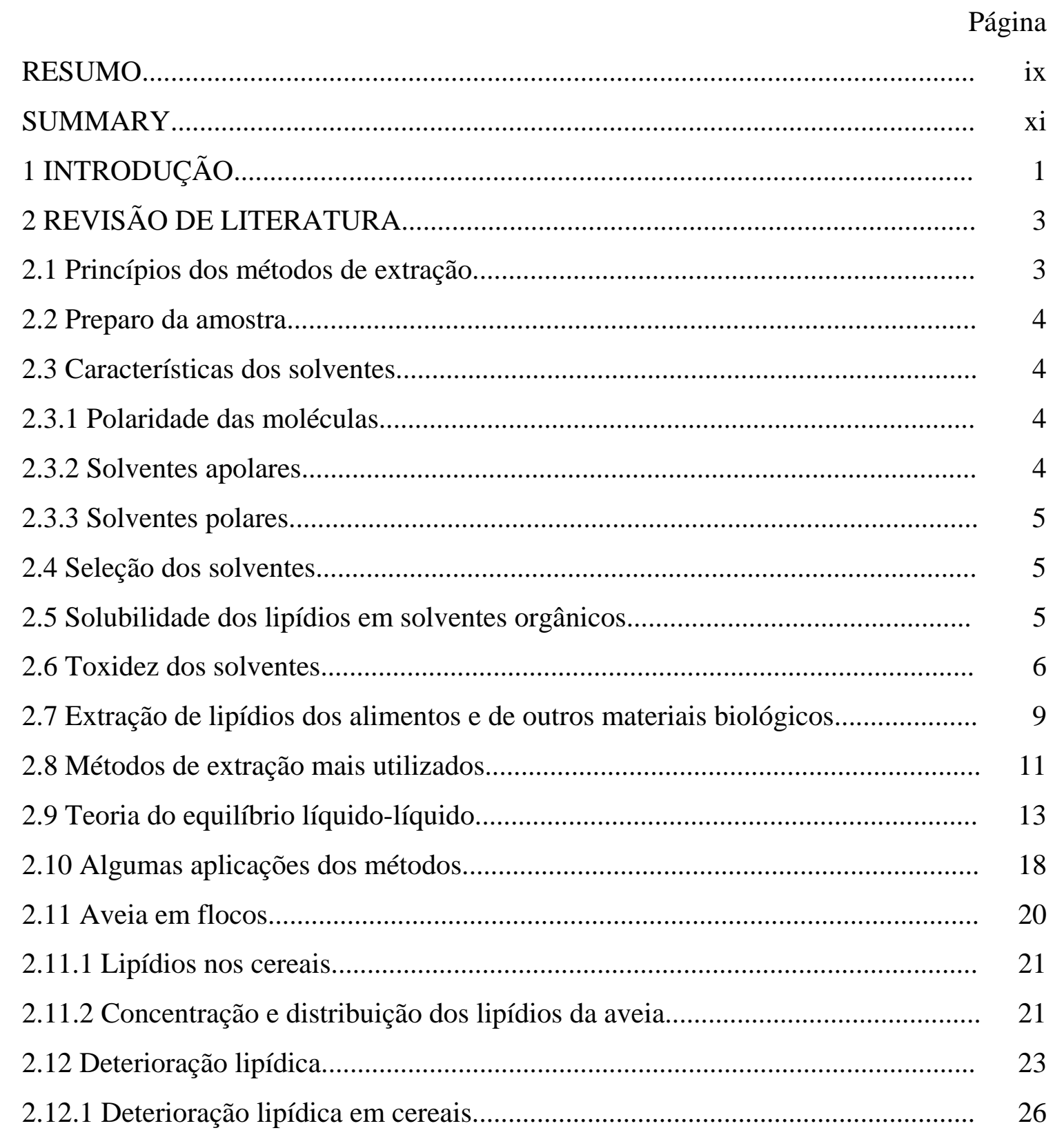


2.12.2 Qualidade dos grãos de aveia.............................................................. 27

2.12.3 Oxidação lipídica em carnes e produtos cárneos......................................... 28

2.12.3.1 Peito de frango............................................................................... 28

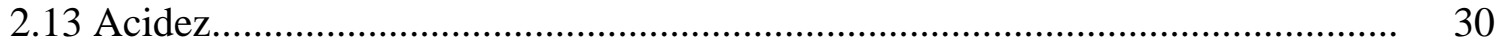

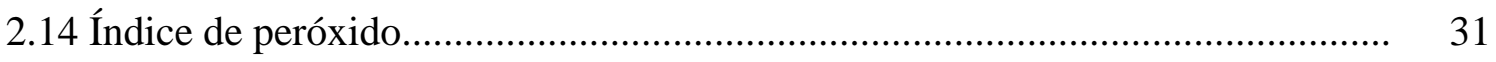

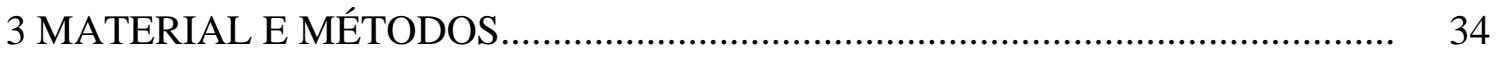

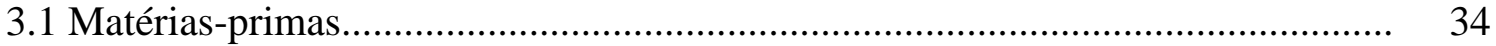

3.2 Métodos de extração da fração lipídica nas amostras selecionadas..................... 34

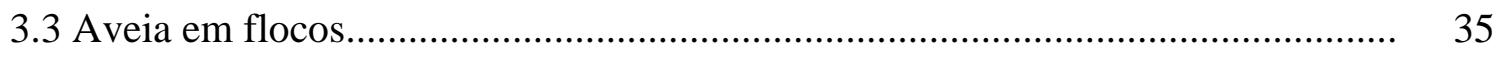

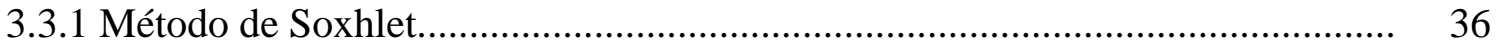

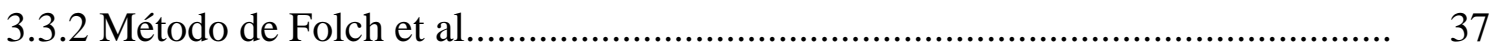

3.3.3 Método de Bligh \& Dyer.......................................................................... 37

3.3.4 Método de Hara \& Radin............................................................................. 38

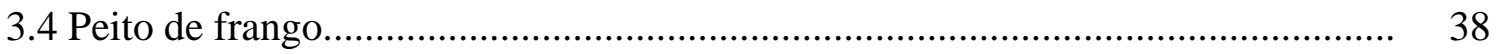

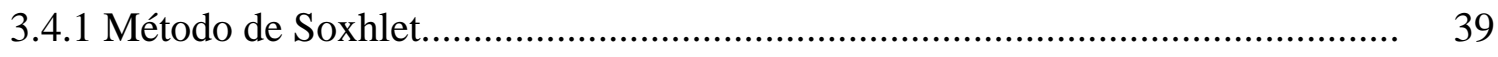

3.4.2 Método de Folch et al.............................................................................. 39

3.4.3 Método de Bligh \& Dyer.......................................................................... 39

3.4.4 Método de Hara \& Radin............................................................................. 40

3.5 Análises físico-químicas.......................................................................... 40

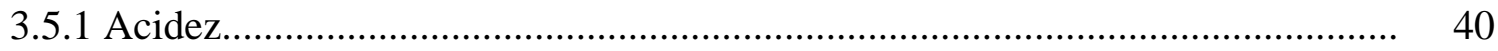

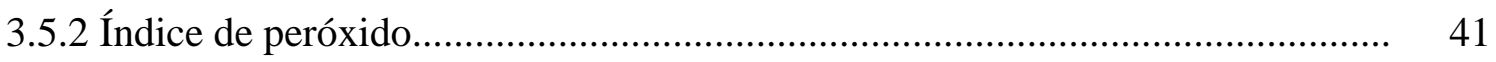

3.6 Teor de óleo das miscelas........................................................................... 41

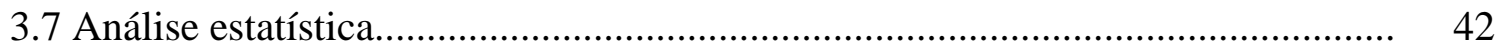

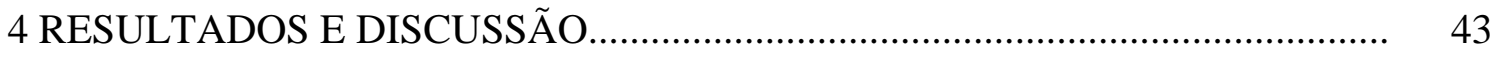

4.1 Avaliação dos métodos aplicados..................................................................... 43

4.2 Análises da qualidade da fração lipídica........................................................... 50

4.2.1 Acidez e índice de peróxido..................................................................... 50

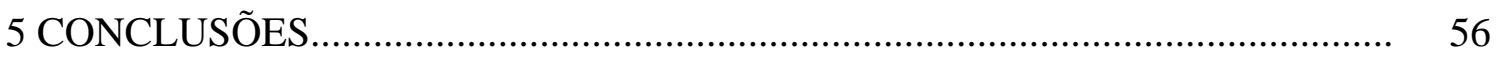

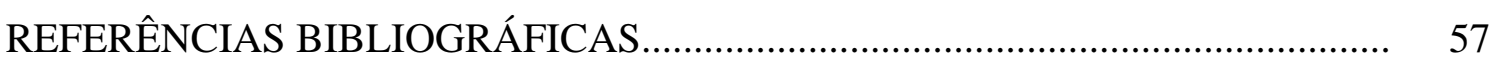




\section{MÉTODOS DE EXTRAÇÃo E QUALIDADE DA FRAÇÃO LIPÍDICA}

Autor: AELSON ALOIR SANTANA BRUM

Orientadora: Prof ${ }^{a}$. Dra . MARISA APARECIDA BISMARA REGITANO-D’ARCE

\section{RESUMO}

Um estudo crítico foi realizado utilizando quatro métodos clássicos de extração de lipídios em aveia em flocos e peito de frango. Foram comparados os rendimentos, o tempo de extração, a repetibilidade de cada método e a qualidade oxidativa da fração lipídica obtida. As metodologias utilizadas foram as de Soxhlet, com n-hexano como solvente, nos períodos de quatro e oito horas de extração; Folch et al., com clorofórmio e metanol na proporção de 2:1 (v/v); Bligh \& Dyer, com clorofórmio, metanol e água na proporção de 1:2:0,8 (v/v) e Hara \& Radin, com n-hexano e isopropanol, na proporção de 3:2 (v/v). Os resultados obtidos indicaram que para a aveia em flocos, os métodos de Soxhlet e Bligh \& Dyer apresentaram um rendimento superior (7,71 \% e 7,66 \%, respectivamente) em relação ao método de Hara \& Radin e Folch et al. (6,61 \% e 6,93 \%, respectivamente). No estudo do peito de frango, os métodos de Soxhlet, Folch et al. e Bligh \& Dyer apresentaram um rendimento satisfatório de lipídios totais, sendo, respectivamente, de 1,56 \%, 1,56 \% e 1,65 \%. Apesar do bom rendimento em lipídios totais, o método de Soxhlet afetou a qualidade da fração lipídica em ambas amostras, demonstrada pela presença de peróxidos (4,39 e 4,19 meq $\mathrm{O}_{2} / \mathrm{kg}$ no peito de frango; 3,71 e 3,70 meq $\mathrm{O}_{2} / \mathrm{kg}$ na aveia em flocos) e pela acidez oléica (2,58 \% de ácidos graxos livres (AGL) no peito de frango; 2,25 e 2,24 \% AGL na aveia em flocos), 
em ambos os períodos de tempo da extração. Com base nos resultados deste trabalho, indica-se a metodologia de Bligh \& Dyer para os casos em que haja interesse em uso posterior das frações lipídicas, em detrimento da de Soxhlet, não recomendável para o fim mencionado. 


\title{
EXTRACTION METHODS AND QUALITY OF THE LIPID FRACTION
}

\author{
Author: AELSON ALOIR SANTANA BRUM \\ Adviser: Prof ${ }^{\mathrm{a}}$. Dr ${ }^{\mathrm{a}}$. MARISA APARECIDA BISMARA REGITANO-D’ARCE
}

\section{SUMMARY}

A critical study was carried through with four clasical methods of extraction of lipids from chicken breast and oat flakes. The yield, the extraction time, the repeatability of each method and the oxidative quality of the lipid fraction were evaluated and compared. The methodologies evaluated were Soxhlet, with $n$-hexane as the solvent, in periods of four and eight hours of extraction; Folch et al., with chloroform and methanol in the ratio of 2:1 (v/v); Bligh \& Dyer, with chloroform, water and methanol, in the ratio of 1:2:0.8 (v/v), and Hara \& Radin, with $n$-hexane and isopropanol, in the ratio of 3:2 $(\mathrm{v} / \mathrm{v})$. The results indicated that for oat flakes, the methods Soxhlet and Bligh \& Dyer presented higher yields in total lipids (7.71 \% and $7.66 \%$, respectively) than the methods Hara \& Radin and Folch et al. (6.61 \% and $6.93 \%$, respectively). In the study with chicken breast, the methods Soxhlet, Folch et al. and Bligh \& Dyer presented the highest yields, being respectively $1.56 \%, 1.56 \%$ and $1.65 \%$.Despite the good yields in total lipids, the Soxhlet method affected the quality of the lipid fraction in both samples, demonstrated by the presence of peroxides (4.39 and 4.19 meq $\mathrm{O}_{2} / \mathrm{kg}$ in chicken breast; 3.71 and 3.70 meq $\mathrm{O}_{2} / \mathrm{kg}$ in oat flakes) and by the acid values (2.58 \% FFA [free fatty acids] in chicken breast for both extractions; 2.25 and 2.24 \% FFA in oat flakes,) for both periods of time evaluated. Based on the results obtained in this research, the authors 
recommend Bligh \& Dyer methodology whenever there is interest in further use of the lipid fraction and strongly disencourage Soxhlet method for the purpose mentioned. 


\section{INTRODUÇÃO}

A extração de lipídios é uma determinação importante em estudos bioquímicos, fisiológicos e nutricionais dos mais diversos tipos de alimentos e, portanto deve ser realizada com acurácia. Algumas amostras requerem cuidados especiais para a obtenção da fração lipídica, pois fatores como co-extração dos componentes nãolipídicos e a oxidação indesejada podem influenciar a qualidade final da fração lipídica. Os procedimentos clássicos nos quais o tecido é submetido à extração em um aparelho do vidro idealizado por Soxhlet em 1879, com refluxo de solvente por muitas horas, devem ser evitados, já que favorecem as reações de peroxidação e de hidrólise (Kates, 1972), podendo comprometer resultados analíticos posteriores, como o da quantificação de certos componentes lipídicos ou não. Um dos procedimentos de extração mais versáteis e efetivos, que supera amplamente algumas dificuldades mencionadas acima, é a metodologia de Bligh \& Dyer, uma versão simplificada do procedimento clássico usando clorofórmio-metanol proposto Folch et al. (1957).

A extração de lipídios é importante sob dois aspectos: na nutrição, pois uma alimentação equilibrada exige o conhecimento da composição bromatológica de um alimento; e, segundo, o monitoramento de contaminantes orgânicos (dioxinas, PCB's, pesticidas organoclorados) que são quantificados, geralmente, na fração lipídica (Manirakiza et al., 2001).

Considerando principalmente os riscos potenciais, tanto à saúde como ao meio ambiente, dos métodos que se baseiam no uso da mistura clorofórmio-metanol, Hara \& Radin (1978) e, em seguida Radin (1981), propuseram um método bastante simples, e menos tóxico, baseado no uso de uma mistura de $n$-hexano-isopropanol. Além da baixa toxidez dos solventes utilizados, outros fatores devem ser levados em consideração na 
escolha dos solventes para a extração da fração lipídica de determinada matriz: a volatilidade, a ausência de impurezas, de natureza tóxica ou que reajam com os lipídios, a capacidade de formar um sistema de duas fases com água (para remoção dos nãolipídios), o poder de extração de componentes indesejáveis (lipoproteínas, pequenas moléculas), o poder de extração dos diferentes tipos de lipídios, a transparência na região da luz ultravioleta para subseqüentes análises espectrofotométricas ou em colunas cromatográficas e o custo para a realização dos procedimentos (Hara \& Radin, 1978). 


\section{REVISÃO DE LITERATURA}

\subsection{Princípios dos métodos de extração}

A extração de óleo com solvente é um processo de transferência de constituintes solúveis (o óleo) de um material inerte (a matriz graxa), para um solvente com o qual a matriz se acha em contato. Os processos que ocorrem são meramente físicos, pois o óleo transferido para o solvente é recuperado sem nenhuma reação química (Regitano-d’Arce, 1991).

A primeira tarefa na análise dos lipídios de um alimento é extraí-los com um solvente. Lipídios hidrofóbicos, como os triacilgliceróis e colesterol, estão geralmente presentes como grandes glóbulos e são facilmente extraídos pela maioria dos solventes, incluindo hidrocarbonetos, como o éter de petróleo e $n$-hexano. Lipídios anfilílicos, como os fosfolipídios e glicolipídios, estão fortemente associados com proteínas e água, contribuindo para a formação da estrutura do alimento (Gurr, 1992).

Os procedimentos para extração dos lipídios de tecidos animais ou vegetais exigem a observação de alguns passos importantes: 1) o pré-tratamento ou preparo da amostra (o qual pode incluir secagem, redução do tamanho da amostra ou hidrólise ácida); 2) homogeneização do tecido na presença de um solvente; 3) separação das fases líquida (orgânica e aquosa) e sólida; 4) remoção dos contaminantes não-lipídicos; 5) remoção do solvente e secagem do extrato (Shahidi \& Wanasundara, 1998). 


\subsection{Preparo da amostra}

O preparo da amostra para análise lipídica depende do tipo do alimento e da natureza da sua composição lipídica. Para obtenção de resultados confiáveis é recomendável o conhecimento da estrutura, da química e da ocorrência das principais classes lipídicas e seus constituintes. O uso de altas temperaturas deve ser evitado, e a manutenção de uma atmosfera inerte durante a preparação da amostra e extração pode minimizar as reações de oxidação dos lipídios insaturados.

\subsection{Características dos solventes}

\subsubsection{Polaridade das moléculas}

O conceito de polaridade de uma ligação está relacionado com o compartilhamento desigual dos elétrons entre dois átomos, que leva a uma separação parcial da carga positiva e negativa. O conceito de polaridade é útil para descrever moléculas inteiras que exibem uma separação parcial de cargas. Uma molécula nãopolar é aquela em que a posição média de todas as cargas positivas na molécula, chamada de centro das cargas positivas, coincide com a posição média de todas as cargas negativas, o centro das cargas negativas. Numa molécula polar, existe uma separação de cargas, ou seja, os dois centros não coincidem. Moléculas polares são conhecidas como dipolos (Russel, 1994).

\subsubsection{Solventes apolares}

Em substâncias não-polares, as únicas atrações intermoleculares são as forças fracas de London. Assim, quando soluções destes componentes são formadas, as interações soluto-soluto e solvente-solvente são facilmente substituídas pelas interações soluto-solvente. Quando moléculas do soluto não-polar são introduzidas entre moléculas de solvente apolar, há uma mudança do meio muito pequena para ambas e, então, a 
solução é formada facilmente. Por outro lado, solventes não polares não são bons solventes para compostos iônicos e polares (Russel, 1994).

\subsubsection{Solventes polares}

Um bom exemplo de solvente polar é a água. A água é um solvente muito bom para compostos iônicos, porque as forças íon-dipolo estabelecidas nas soluções são fortes (a água é uma molécula de alta polaridade), e cada íon é envolvido por muitas moléculas de $\mathrm{H}_{2} \mathrm{O}$. Todavia a água é um mau solvente para substâncias apolares. Isso é verdade porque as interações solvente-solvente (dipolo-dipolo) na água são tão fortes que elas não podem ser superadas pelas fracas forças soluto-solvente, tais como aquelas originadas por um soluto apolar (Russel, 1994).

\subsection{Seleção dos solventes}

A insolubilidade dos lipídios em água torna possível sua separação das proteínas, carboidratos e da água nos tecidos. Como os lipídios têm uma grande faixa de relativa hidrofobicidade, é praticamente inviável a utilização de um único solvente universal para a extração dos lipídios (Shahidi \& Wanasundara, 1998). Lipídios neutros estão ligados covalentemente e podem ser extraídos dos tecidos por solventes apolares, enquanto lipídios polares, os quais estão ligados por forças eletrostáticas e pontes de hidrogênio, requerem solventes polares capazes de quebrar tais ligações e liberá-los.

\subsection{Solubilidade dos lipídios em solventes orgânicos}

Lipídios simples e puros são solúveis em uma grande variedade de solventes orgânicos, mas muitos destes solventes não são adequados para a extração dos lipídios de tecidos, bem como não são suficientemente polares para superar as forças de associação entre os tecidos lipídicos e os outros constituintes celulares, tais como as proteínas. Apesar disso, lipídios polares complexos, os quais não dissolvem prontamente 
em solventes apolares, podem, em algumas ocasiões, ser extraídos por esses solventes, quando eles estão na presença de grandes quantidades de lipídios simples, tais como triglicerídios (Christie, 1982).

O uso de um único solvente não é recomendável para a extração dos lipídios de tecidos animais. O solvente ou a mistura de solventes ideal para extração da matéria graxa de tecidos deve ser suficientemente polar para removê-las das associações com as membranas celulares ou com lipoproteínas, sem que ocorra qualquer reação química (Christie, 1982).

Pesquisadores, como Folch et al. (1957), reconheceram estas características intrínsecas da extração de lipídios e desenvolveram um método usando uma mistura de clorofórmio e metanol, seguida pela adição de solução de $\mathrm{KCl}$, visando uma melhor separação das fases. Bligh \& Dyer modificaram o método de Folch et al. (1957) e propuseram um “método rápido para extração e purificação dos lipídios totais” (Bligh \& Dyer, 1959).

\subsection{Toxidez dos solventes}

Em uma época em que aumentam as preocupações com os problemas causados ao meio ambiente por diversos produtos químicos, o pesquisador da área de lipídios deve considerar as conseqüências que podem surgir quando da escolha dos solventes com que irá trabalhar. E não há somente a preocupação quanto ao meio ambiente, como também existe o risco ao próprio organismo humano. Alguns solventes utilizados na extração de lipídios estão listados no Quadro 1. 


\begin{tabular}{|cc|}
\hline Solvente & Toxidez \\
Clorofórmio & média \\
Benzeno & alta \\
Tolueno & alta \\
Xileno & média \\
Tetracloreto de carbono & abaixo da média \\
Metanol & alta \\
Ácido acético & concentrado, alta; diluído, baixa \\
Éter dietílico & média \\
Álcool etílico & abaixo da média \\
Hidrocarbonetos clorados & média para muito alta \\
Hidrocarbonetos aromáticos & média para muito alta \\
\hline
\end{tabular}

Quadro 1 - Solventes orgânicos usados na extração de lipídios conhecidos por serem tóxicos

Fonte: Nelson (1991)

Dentre os métodos de extração de lipídios utilizados por pesquisadores do mundo inteiro, os mais conhecidos e, geralmente, mais efetivos e com melhor rendimento, são os que utilizam a mistura clorofórmio e metanol. Os métodos de Folch et al. (1957) e Bligh \& Dyer (1959) são eficazes na extração de lipídios totais, principalmente os polares, mas têm diversas desvantagens. Sabe-se que o metanol é nitidamente tóxico, produzindo dores de cabeça se o local de trabalho não for adequadamente ventilado e o clorofórmio é suspeito de ser carcinogênico. Esta mistura de solventes também apresenta a desvantagem de ser de custo elevado e possui a característica indesejável de dissolver apreciáveis quantidades de não-lipídios, por exemplo, algumas proteínas. O armazenamento prolongado de clorofórmio pode levar à formação de fosgênio e ácido clorídrico (Nelson, 1991). 
A mistura de $n$-hexano e isopropanol têm se mostrado adequada na substituição de clorofórmio e metanol, principalmente no que diz respeito à toxidez (Radin, 1981). A mistura alternativa ao clorofórmio e metanol consiste de um solvente de baixa polaridade ( $n$-hexano) e outro de alta polaridade (isopropanol); sendo miscível em água pode penetrar na membrana celular e dissolver uma vasta categoria de lipídios que diferem consideravelmente quanto a sua solubilidade (Radin, 1981). Outra vantagem dessa extração, observada experimentalmente, é que durante a separação das fases, a fase orgânica contendo os lipídios fica na parte superior do funil de extração, facilitando sua remoção e evitando uma indesejável contaminação. O Quadro 2 apresenta algumas alternativas menos tóxicas para extração da matéria graxa.

\begin{tabular}{|cc|}
\hline Solvente & Comentários \\
$\begin{array}{c}\text { Saturado, hidrocarboneto de cadeia } \\
\text { longa (pentano, } n \text {-hexano, } \\
\text { superiores ao octano) } \\
\text { Isopropanol }\end{array}$ & $\begin{array}{c}\text { Cadeias com mais de } 8 \text { carbonos não são bons } \\
\text { solventes para lipídios; alto ponto de ebulição, de } \\
\text { cadeias curtas são irritantes para a pele. } \\
\text { Pode ser tóxico se ingerido. }\end{array}$ \\
Acetona & Alto ponto de ebulição, inconveniente para sua \\
Isoctano & remonão do extrato. \\
Metil etil cetona & Irritante no contato com a pele e os olhos. \\
Ciclohexano & Pode ser tóxico se ingerido. \\
& Pode ser tóxico se ingerido, irritante à pele. \\
Não é bom solvente para lipídios.
\end{tabular}

Quadro 2 - Alguns solventes orgânicos de baixo risco ao meio ambiente e baixa toxicidade

Fonte: Nelson (1991) 


\subsection{Extração de lipídios dos alimentos e de outros materiais biológicos}

Há três tipos principais de associações das quais os lipídios participam nos tecidos orgânicos: i) forças de Van der Waals não polares; ii) pontes de hidrogênio e forças eletrostáticas; iii) ligações covalentes. Os lipídios que estão em grande parte ligados por forças de Van der Waals ou hidrofóbicas, através das quais lipídios neutros ou não polares estão ligados por forças razoavelmente fracas, podem ser extraídos com solventes relativamente não polares tais como clorofórmio e o benzeno. Lipídios polares associados a membranas, entretanto, requerem solventes com certa polaridade, tais como etanol ou metanol, para romper as pontes de hidrogênio ou forças eletrostáticas entre eles e as proteínas. Os lipídios ligados hidrofobicamente, ao contrário, não podem ser diretamente extraídos por quaisquer solventes porque, primeiro, deve ser rompida a ligação do complexo por hidrólise ácida ou alcalina (Nelson, 1991).

A liberação de triglicerídios de tecidos da estrutura celular é geralmente considerada como um transporte extrativo ligado a uma parte sólida. Para isto considerase como pré-requisito a completa desintegração do material antes da extração. No processo de liberação extrativa, levam-se em conta três etapas principais: (1) a penetração do solvente no tecido; (2) a formação de uma miscela intracelular e (3) a difusão do extrato na miscela externa (Schneider, 1980).

"De acordo com Coats \& Karnofsky (1950), quando os materiais oleaginosos são preparados para a extração, são moídos em pequenos grânulos ou transformados em flocos, ambos apresentando uma estrutura porosa. Um floco é composto de óleo, água, espaços de ar e partículas isentas de óleo. Quando um floco é imerso no solvente, o espaço de ar é preenchido com ele, apresentando composição semelhante à do líquido circundante. À medida que a extração ocorre, o espaço ocupado pelo óleo vai sendo preenchido pelo líquido. Esta solução, ocupante dos espaços vazios, está retida no interior do floco de forma estática, e não drena. O óleo passa a ser considerado em duas frações: a fração contida no interior, que é influenciada pela concentração da solução circundante; e a fração original de óleo, que ainda não foi transferida do sólido para a solução, que é denominada de “óleo não dissolvido”. O farelo completamente drenado e 
esgotado, após a evaporação do solvente, contém uma quantidade de óleo que é a soma destas duas frações" (Regitano-d’Arce, 1991).

Segundo Schneider (1980) a condição para a liberação de lipídios é a ocorrência de uma variação da permeabilidade, que somente pode se estabelecer quando ocorrer, em função da formação da pressão osmótica, uma deformação da membrana.

A tendência de solubilização dos lipídios leva à formação de uma pressão no lado lipídico de uma membrana semi-permeável, sendo que essa pressão provoca uma dilatação da membrana, provocando uma alteração na sua permeabilidade.

O processo de dissolução na extração por solvente está baseado nas leis da termodinâmica e envolve dois processos endotérmicos e um exotérmico. Em um primeiro estágio, as moléculas do soluto (seja sólido ou líquido) separam-se em moléculas isoladas. Este é um processo endotérmico. Esta energia é chamada "energia latente", "calor de sublimação" ou "calor de vaporização" e é pequena quando as moléculas do soluto são apolares. Em seguida, as moléculas separadas do soluto se dispersam no solvente. É necessário energia para que as moléculas do solvente se dissociem para acomodarem as moléculas do soluto. Esta energia necessária é tanto maior quanto mais fortes sejam as interações intermoleculares no solvente puro, conforme a seguinte ordem: solventes apolares < solventes polares < solventes com ligações de hidrogênio (Johnson \& Lusas, 1983).

No terceiro processo (exotérmico), as moléculas dispersas de soluto interagem com as moléculas vizinhas do solvente. A energia liberada aumenta na seguinte ordem conforme o tipo de interações soluto-solvente: ambas moléculas do soluto e solvente são polares < um é polar e o outro apolar < ambas moléculas são polares (Johnson \& Lusas, 1983).

A natureza química dos lipídios a serem extraídos deve ser levada em consideração na escolha dos procedimentos e a temperatura de extração deve ser a ambiente a fim de retardar a formação de peróxidos e hidrólise de ácidos graxos livres. 


\subsection{Métodos de extração mais utilizados}

O método clássico de Soxhlet (1879) é, sem dúvida, a técnica mais antiga e difundida para extração de lipídios de amostras de alimentos, sendo uma das principais metodologias adotadas como referência de eficiência da extração.

O primeiro aparelho foi desenvolvido por Franz von Soxhlet em 1879, que ressaltou a importância do grau de trituração da amostra quanto à duração e eficácia do processo. Consiste no tratamento sucessivo e intermitente da amostra imersa em um solvente puro (éter de petróleo, éter dietílico ou $n$-hexano), graças à sifonagem e subseqüente condensação do solvente aquecido dentro do balão que está na base do aparelho.

As mais notáveis vantagens que o método de Soxhlet (1879) apresenta são: a amostra está sempre em contato com o solvente, havendo a sua constante renovação; a temperatura do sistema mantém-se relativamente alta, visto que o calor aplicado para o processo de evaporação é constante; é uma metodologia muito simples que não requer treinamento especializado e que possibilita a extração de uma quantidade maior de óleo em relação a outros métodos, sem a necessidade de filtração da miscela após o término da extração, pois a amostra esteve envolta no cartucho durante todo o procedimento (Luque de Castro \& García-Ayuso, 1998).

Os principais inconvenientes que o método de Soxhlet (1879) apresenta são o longo tempo requerido para a extração e o grande volume de solvente utilizado, o qual não é somente de alto custo, mas também pode ser nocivo à saúde e ao meio ambiente. Quando amostras que contêm elementos termolábeis são analisadas, deve-se levar em consideração que um longo período de extração pode causar a sua decomposição térmica. Devido ao grande volume de solvente utilizado, uma etapa de evaporação ou concentração é geralmente obrigatória ao final do processo para a recuperação da fração lipídica (Luque de Castro \& García-Ayuso, 1998).

Os métodos Aa 4-38 da American Oil Chemists' Society (AOCS, 1997), para produtos de origem vegetal, 960.39 para carnes e produtos cárneos e 920.85, para cereais, ambos da Association of Official Analytical Chemists (AOAC, 1995), utilizados 
para determinação do teor de óleo destes alimentos, recomendam o uso de um aparelho semelhante ao de Soxhlet, sem, no entanto, a presença do sifão, e, com éter de petróleo como solvente de extração. Denominado de aparelho de Butt, a diferença é que nesta metodologia o solvente aquecido é evaporado diretamente pela câmara de extração e, condensado, goteja sobre a parte superior do cartucho, percolando a amostra e lixiviando a fração lipídica dissolvida para o balão. A diferença entre estes dois sistemas reside nos processos ocorrerem por percolação, no caso do Butt, e por imersão no solvente, no caso do Soxhlet. Para que a extração seja eficaz e rápida, a velocidade de gotejamento recomendada é de, no mínimo, 150 gotas por segundo, o que permite a extração total em um período de quatro horas.

Mehlenbacher (1960) ressaltou que a vantagem deste último tipo de extrator sobre o sistema intermitente de Soxhlet, era a de uma maior recuperação da matéria graxa. Para melhores resultados, salientou o autor, a intensidade de aquecimento e a velocidade de condensação devem ser ajustadas para que o solvente possa envolver continuamente a amostra, graças ao gotejamento constante.

As Normas Analíticas do Instituto Adolfo Lutz (1985) recomendam o uso do aparelho de Soxhlet para a determinação dos lipídios totais, com éter de petróleo como solvente (método 4.10). A International Union of Pure and Applied Chemistry (IUPAC, 1979), através do método 1.122, não especifica qual tipo de aparelho deve ser usado na determinação do conteúdo lipídico dos alimentos, porém indica o $n$-hexano como solvente adequado para a realização do procedimento.

Apesar de algumas desvantagens, os métodos de Folch et al. (1957) e Bligh \& Dyer (1959) são largamente utilizados, tanto como propostos originalmente, quanto modificados (Hanson \& Olley, 1963; Christie, 1982; Nelson, 1991; Hole et al., 1996; Schäfer, 1998; Smedes, 1999; Smedes \& Askland, 1999; Undeland, 1998; Iverson, 2001; Manirakiza et al., 2001). Entre as desvantagens podemos citar a toxidez dos solventes usados e a indesejável extração dos contaminantes não-lipídicos da fase orgânica. Este problema está relacionado com a quantidade de água do tecido do qual se está extraindo o lipídio e, conseqüentemente, a proporção de água adicionada. Além disso, as lavagens são fatores importantes na eficiência da extração. 


\subsection{Teoria do equilíbrio líquido-líquido}

Uma das vantagens do método desenvolvido por Bligh \& Dyer (1959) é a formação de um sistema bifásico a partir das proporções de solventes adicionados durante o processo de extração. A formação desse sistema bifásico está baseada na teoria do equilíbrio líquido-líquido de três componentes (clorofórmio/metanol/água). A determinação das solubilidades de cada componente pode ser avaliada através de um diagrama ternário de solubilidade de dois líquidos parcialmente miscíveis entre si (clorofórmio e água) com um terceiro (metanol), completamente miscível nos outros dois.

À pressão e temperatura constantes o diagrama de fases é apresentado na forma triangular (Figura 1), no qual cada vértice corresponde ao componente puro (Bueno \& Degrève, 1980).

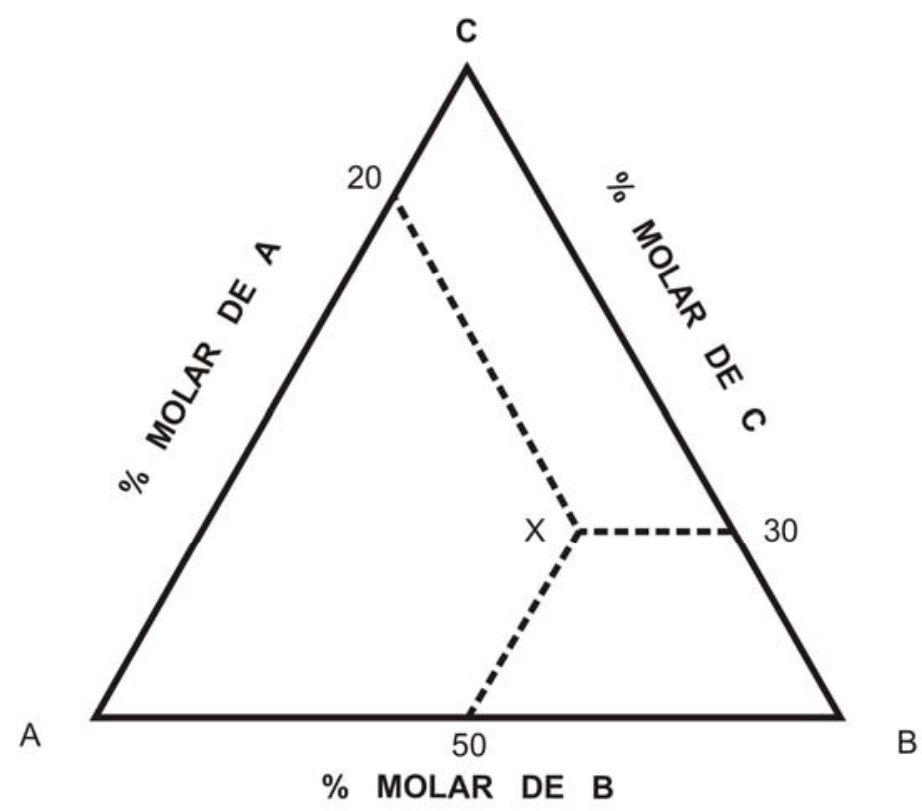

Figura 1 - Diagrama de fases de um sistema ternário

Fonte: Bueno \& Degrève (1980)

A Figura 1 mostra as coordenadas de um sistema de três componentes, $A, B$ e C. A linha $A B$ representa as percentagens molares de $B$ e as linhas $C A$ e $B C$ as 
percentagens molares de $A$ e $C$, respectivamente. Deste modo, qualquer reta paralela a um dos lados do triângulo representa uma composição constante do componente locado no vértice oposto (perpendicular). Por exemplo, na adição de 20 \% da solução A, 50 \% da solução B e 30 \% da solução C, obtém-se o ponto X.

Experimentalmente, um diagrama de fases ternário pode ser obtido preparando-se misturas conhecidas de dois líquidos pouco miscíveis. A água e o clorofórmio são imiscíveis à temperatura ambiente e, adicionando-se a esta mistura porções de metanol, ele se distribuirá nas duas camadas de modo a permitir que certa quantidade de água se dissolva no clorofórmio. O metanol pode ser adicionado de modo que as composições de fase em contato se aproximem cada vez mais até se igualarem, definindo um ponto crítico isotérmico no sistema ("plait point"), ou seja, onde as composições das duas fases em equilíbrio tornam-se idênticas (Bueno \& Degrève, 1980).

As composições de cada camada podem ser determinadas através de métodos analíticos. No diagrama de solubilidade elas são definidas por dois pontos, por exemplo, os pontos $a^{\prime}$ e $b^{\prime}$ da Figura 2, os quais, unidos, fornecem uma reta denominada "tie line".

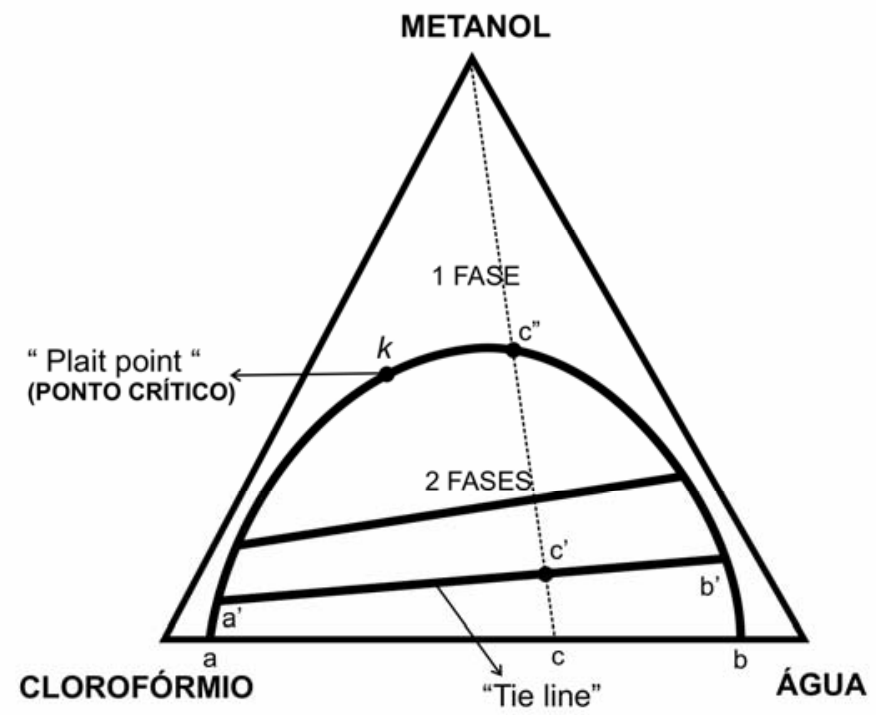

Figura 2 - “Tie-line” no diagrama de fases ternário de água, clorofórmio e metanol Fonte: Bueno \& Degrève (1980) 
As “tie-lines” são linhas de correlação entre duas soluções conjugadas ( $a^{\prime}$ e $b^{\prime}$ na Figura 2) e estão localizadas no interior da curva binodal. A curva binodal expressa as composições termodinamicamente estáveis e separa a região bifásica da região homogênea. Essa curva é obtida a partir da derivação da energia livre de mistura do sistema, em função da composição. Na Figura 2 verifica-se que na parte interna da curva binodal, o sistema apresenta duas fases e à medida que o metanol é adicionado, a composição varia (presença de outras "tie-lines”) e, num determinado momento, a camada mais rica em água aumenta em quantidade, enquanto que a outra, rica em clorofórmio, diminui. Em c" existem somente traços da camada rica em clorofórmio, e acima de c” o sistema é homogêneo (Castellan, 1973; Atkins, 1992).

Como as linhas de correlação não são paralelas, o ponto em que as duas soluções conjugadas possuem a mesma composição não se localiza no topo da curva binodal, mas fica em um dos lados, no ponto $k$ (Figura 2) denominado de ponto crítico de solubilidade (“plait point”) (Atkins, 1992).

Bligh \& Dyer (1959) propuseram um método rápido de extração dos lipídios totais, utilizando amostras de músculo de bacalhau. Com o objetivo de atingir condições ótimas para a extração lipídica, os pesquisadores aplicaram a teoria do equilíbrio líquido-líquido de três componentes.

Na prática, o primeiro passo foi encontrar quais das várias misturas de clorofórmio e metanol renderiam uma extração quantitativa e eficiente (Quadro 3). 


\begin{tabular}{|ccccccccc}
\hline \multicolumn{3}{|c}{ Mistura inicial de extração } & \multicolumn{5}{c|}{ Diluição dos solventes } \\
Pontos no & Clorofórmio & Metanol & Água* & Clorofórmio & Água & Volume & Lipídios (g) \\
diagrama & $($ nigura 3) & $(\mathrm{mL})$ & $(\mathrm{mL})$ & $(\mathrm{mL})$ & $(\mathrm{mL})$ & $\begin{array}{c}(\mathrm{mL}) \\
\text { total }(\mathrm{mL})\end{array}$ & $\begin{array}{c}\text { nase } \\
\text { clorofórmio }\end{array}$ \\
A & 23 & 144 & 80 & 40 & 87 & 374 & 0,31 \\
B & 54 & 202 & 80 & 104 & 154 & 594 & 0,56 \\
C & 94 & 228 & 80 & 166 & 184 & 752 & 0,63 \\
D & 162 & 270 & 80 & 285 & 228 & 1025 & 0,64 \\
E & 296 & 355 & 80 & 290 & 325 & 1346 & 0,62 \\
F & 97 & 121 & 80 & $\S$ & $\S$ & 298 & 0,56 \\
G & 50 & 174 & 160 & $\S$ & $\S$ & 384 & 0,32 \\
H & 54 & 87 & 80 & $\S$ & $\S$ & 221 & 0,32 \\
I & 96 & 80 & 80 & $\S$ & $\S$ & 256 & 0,40 \\
J & 175 & 76 & 80 & $\S$ & $\S$ & 331 & 0,41 \\
P & 100 & 200 & 80 & 100 & 100 & 580 & 0,70 \\
\hline
\end{tabular}

Quadro 3 - Lipídios extraídos de 100 g do músculo de bacalhau pelas misturas ternárias clorofórmio-metanol-água

Fonte: Bligh \& Dyer (1959)

* Incluindo $80 \mathrm{~mL}$ de água do tecido

§ Não foi necessária a adição de solventes para render um sistema bifásico

Os solventes foram misturados em proporções tais que, com a água das amostras, as misturas ternárias foram formadas, tendo composições como as mostradas no diagrama de fases (Figura 3, pontos $\mathrm{A}-\mathrm{J}$ ).

As amostras de bacalhau (100 g) foram homogeneizadas com os solventes e filtradas, rendendo um sistema bifásico. A composição final dessas misturas ternárias é dada pelos pontos A', B', C' e DE’ na Figura 3. 


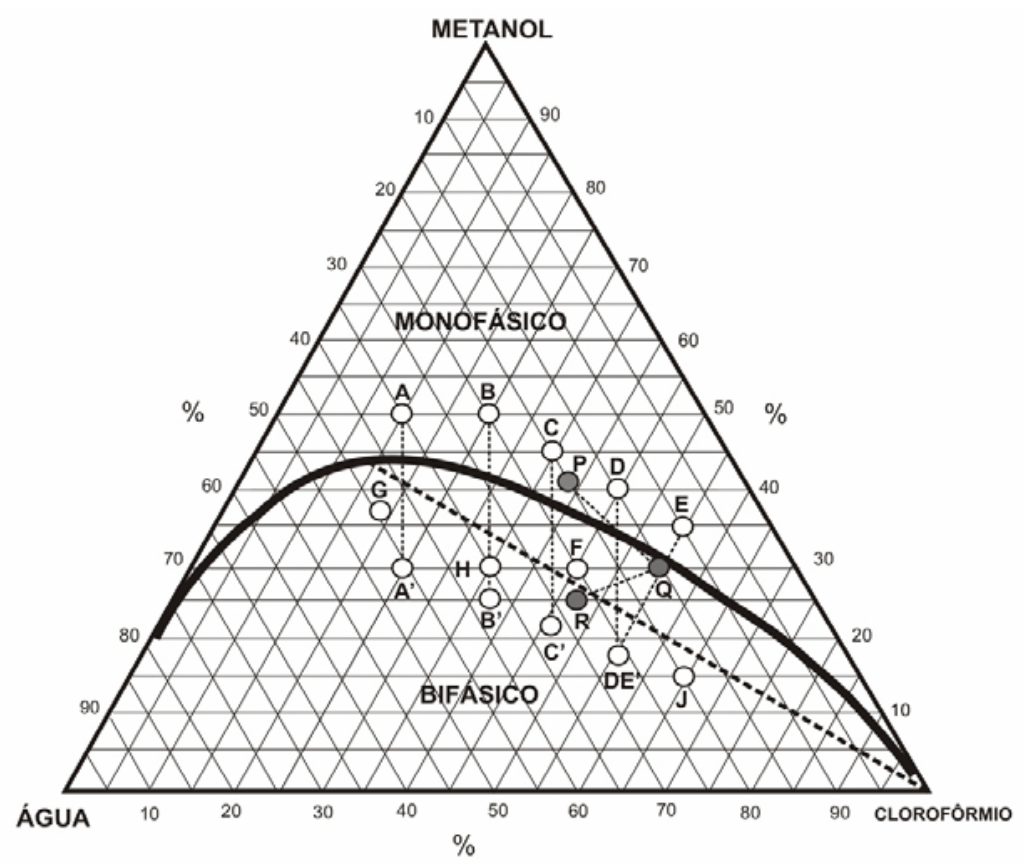

Figura 3 - Diagrama de fases clorofórmio-metanol-água (\%) a $20^{\circ} \mathrm{C}$ (Bligh \& Dyer, 1959)

Os resultados que os pesquisadores encontraram (Quadro 3 e Figura 3) confirmaram a hipótese inicial de que mais lipídios foram extraídos pelas misturas da área monofásica do diagrama do que da área bifásica. O ponto P na área monofásica foi escolhido como um ponto conveniente para posteriores investigações, visto que a composição da mistura era equivalente a $100 \mathrm{~mL}$ de clorofórmio, $200 \mathrm{~mL}$ de metanol e $80 \mathrm{~mL}$ de água. A composição após adição de mais $100 \mathrm{~mL}$ de clorofórmio é representada pelo ponto $\mathrm{Q}$ na área bifásica e o ponto $\mathrm{R}$, que está abaixo da "tie-line máxima de clorofórmio”, é obtido pela subseqüente diluição com 100 mL de água.

Bligh \& Dyer (1959) salientaram que o clorofórmio deve ser adicionado antes da água e cada adição deve ser seguida por agitação. Esse procedimento resulta em uma rápida separação das fases e em um bom rendimento lipídico.

\subsection{Algumas aplicações dos métodos}


Os métodos de Folch et al. (1957), Bligh \& Dyer (1959) e Hara \& Radin (1978) são conhecidos como métodos de extração a frio, pela comparação com o método de Soxhlet (1879), que emprega o calor no processo. Desde o surgimento destes métodos de extração a frio (i.e., à temperatura ambiente), diversos trabalhos foram realizados a fim de que a qualidade da fração lipídica não fosse afetada, o rendimento da extração fosse satisfatório e os solventes utilizados apresentassem um menor grau de toxidez.

Gunnlaugsdoltir \& Ackman (1993) utilizaram três métodos diferentes para extração da fração lipídica da farinha de peixe. Os métodos consistiram de clorofórmiometanol-água, em uma extração bifásica, de acordo com Bligh \& Dyer (1959), e em uma extração monofásica, além de n-hexano-isopropanol, de acordo com Hara \& Radin (1978). Os sistemas de solventes que continham clorofórmio-metanol-água apresentaram um maior rendimento em relação ao método de Hara \& Radin (1978). Este rendimento superior foi explicado pela capacidade que os sistemas testados apresentaram de extrair eficientemente os lipídios polares das membranas celulares.

A extração dos lipídios de arenque, Clupea harengus, foi realizada por Undeland et al. (1998), utilizando quatro métodos diferentes. O objetivo foi avaliar métodos que utilizassem solventes menos tóxicos do que clorofórmio e metanol, e assim propôr uma substituição ao método de Bligh \& Dyer (1959). Os métodos utilizados no estudo foram: Bligh \& Dyer (1959), empregando clorofórmio-metanol-água; Hara \& Radin (1978), com $n$-hexano-isopropanol-água; um método utilizando $n$-heptano-etanolágua (Burton et al., 1985) e a metodologia de Hara \& Radin (1978) com $n$-hexanoisopropanol-água, com modificações em relação aos procedimentos originais. Foram analisados os conteúdos de triglicerídios, fosfolipídios, ácidos graxos livres, tocoferol, hidroperóxidos e dienos conjugados na fração lipídica obtida. A fração extraída com clorofórmio-metanol apresentou o teor mais alto de lipídios totais e de fosfolipídios. A fração lipídica extraída pelo sistema $n$-heptano-etanol-água também forneceu um bom rendimento, sendo somente inferior à do método de Bligh \& Dyer (1959). Os autores acreditaram que otimizações neste método alternativo poderiam torná-lo aplicável para 
extração de lipídios em tecidos animais, substituindo os solventes altamente tóxicos clorofórmio e metanol.

Em trabalho realizado por Manirakiza et al. (2001), verificou-se que o método de Soxhlet, usando diferentes solventes como éter de petróleo, metanol, $n$-hexano, diclorometano:hexano (1:4) e acetona:hexano (1:4), separadamente em cada extração, foi extremamente conveniente para extração da fração lipídica de amostras sólidas que continham alto teor de lipídios, tais como chocolate em pó, margarina, leite em pó e ração para frango. Os métodos de Bligh \& Dyer (1959), usando clorofórmio-metanolágua, e Bligh \& Dyer, modificado por Smedes (1999), utilizando isopropanolciclohexano-água, foram mais adequados para extração de amostras líquidas, tais como leite, ovos e plasma humano. As amostras extraídas com metanol, tanto por Soxhlet (1879) como por Bligh \& Dyer (1959), apresentaram um alto rendimento em óleo, já que o metanol possui um poder de solvatação superior ao dos outros solventes usados, extraindo os lipídios e os não-lipídios da matriz em estudo.

Gandhi et al. (2003) realizaram um minucioso estudo buscando solventes alternativos e menos tóxicos para extração de óleo de soja, haja vista que o $n$-hexano é o solvente universal usado extensivamente na extração dessa oleaginosa. Foram utilizados os solventes puros $n$-hexano, $n$-heptano, $n$-propanol, isopropanol e etanol, além da aplicação de sistemas de solventes aquosos (90:10 n-propanol) e azeótropos, como por exemplo $n$-hexano + isopropanol $(78+22)$, em períodos de extração crescentes até 10 horas. Os pesquisadores concluíram que $n$-heptano, $n$-propanol, isopropanol e etanol foram igualmente efetivos na extração, quando comparados com o n-hexano. As misturas de solventes aquosos também foram eficientes com a vantagem de requerer um menor volume de solvente, porém com o inconveniente de demandar maior energia para remoção da água do solvente.

\subsection{Aveia em flocos}

A aveia na forma de flocos é o principal produto usado na produção de cereais matinais quentes, seguida pelo trigo (Gutkoski, 2000). 
A aveia é uma gramínea de cultivo anual pertencente à família Poaceae, tribo Aveneae e gênero Avena. O grão de aveia é um fruto-semente denominado cariopse, em que parte do fruto está fortemente aderido à semente. Esta por sua vez é constituída pelo embrião e pelo endosperma, sendo este último, composto pela camada de aleurona e pelo endosperma amiláceo. A cariopse se desenvolve dentro de coberturas florais que nada mais são que folhas modificadas e formam parte da palha. As coberturas florais envolvem as cariopses tão firmemente que permanecem aderidas a elas após a colheita e se constituem na casca do grão de aveia (Pedó, 2000).

A cariopse representa em torno de $65-75 \%$ do grão, enquanto as cascas, os restantes 25-35 \%. A proporção de cariopse e cascas é influenciada pelas condições ambientais e genótipos. Youngs (1972) encontrou um rendimento industrial entre 68,2$76,4 \%$ e peso de mil cariopses variando entre 18,7 e 22,7 g, em sete genótipos de aveia cultivados nas mesmas condições ambientais.

Na aveia, a cariopse (amêndoa) é longa e elíptica em sua forma e recoberta com uma fina palha (White, 1995). O grão de aveia pode ser dividido em duas partes principais que são o pericarpo e a semente. A semente é formada pelo endosperma e pelo germe (Pedó, 2000).

O endosperma constitui maior proporção do peso da cariopse, cerca de 80 \%, e é composto por somente um tipo de célula que contém compostos amiláceos e corpos protéicos esféricos de tamanhos variados. O embrião (germe) está situado no lado dorsal da cariopse e entre ele e o endosperma situa-se o escutelo o qual secreta enzimas durante a germinação e está envolvido na transferência de material (alimento) do endosperma para o desenvolvimento do embrião (White, 1995). 


\subsubsection{Lipídios nos cereais}

O conteúdo e a composição dos lipídios em cereais dependem dos procedimentos de extração e purificação (solvente, tempo e temperatura de extração, aparelhos, proporção solvente/soluto, método de purificação, etc.) e também dependem do tratamento que é dado à amostra (tamanho da partícula, conteúdo de água, diferenças nas variedades e classes, condições de crescimento dadas ao grão, etc.) (Chung, 1991).

Alguns conceitos devem ser revisados nesse ponto: “lipídios livres” são a porção facilmente extraível com solventes apolares, tais como éter de petróleo, $n$-hexano, éter dietílico, através de um extrator de Soxhlet ou por agitação. Os “lipídios ligados” são extraídos do resíduo originário da extração, utilizando-se um solvente de maior polaridade, que geralmente é um álcool misturado com uma pequena porção de água. O sistema de $n$-butanol saturado em água é considerado o mais eficiente, principalmente em farinha de trigo; a mistura de clorofórmio e metanol (2:1 v/v) é também comumente empregada (Chung, 1991).

\subsubsection{Concentração e distribuição dos lipídios da aveia}

A aveia apresenta alta concentração de lipídios quando comparada aos demais cereais. A porcentagem de lipídios no grão de aveia varia entre 5,0 e 9,0 \%, sendo superior aos teores encontrados em trigo (2,1 - 3,8 \%), arroz (1,8 - 2,5 \%) e milho (3,9 5,8 \%) (Pedó, 2000).

A aveia apresenta características próprias de processamento devido sua estrutura anatômica e composição química. A casca é cerosa, fibrosa e totalmente indigerível pelos seres humanos. O conteúdo de lipídios da cariopse é alto e está distribuído em todo grão. As enzimas lípases presentes nas camadas externas da cariopse devem ser inativadas (Youngs et al., 1982). Essas enzimas hidrolíticas endógenas são as responsáveis pela instabilidade ao armazenamento de grãos e produtos derivados do cereal (Pedó, 2000). 
O alto teor de proteínas, lipídios e fibra alimentar torna a aveia um cereal diferenciado dos demais. A qualidade nutricional é relativamente alta e muito superior, sendo que os indicadores para estas características variam com o local de cultivo, clima e genótipo.

Entre as principais operações realizadas no processamento industrial da aveia estão a limpeza, o descascamento, o tratamento hidrotérmico e a laminação (flocagem). A etapa de limpeza remove as matérias estranhas e impurezas. O descascamento promove a secagem e classificação por tamanho para permitir uma eficiente remoção das cascas. Na seqüência, as cariopses, são cortadas em dois a quatro pedaços, tratadas hidrotermicamente, laminadas, secas e embaladas (Gutkoski, 1994).

Os componentes lipídicos encontrados em maiores quantidades nas frações farelo, endosperma, escutelo e eixo embrionário do grão de aveia são os triglicerídios, sendo o palmítico e o linoléico os ácidos graxos mais abundantes (Youngs et al., 1977).

A concentração dos lipídios no grão de aveia varia conforme os cultivares, mas a distribuição dos lípides é similar em sua grande maioria. A concentração é mais baixa na casca (menos de $3 \%$ do total dos lipídios) sendo crescente a partir do endosperma (6-8 \%), no germe (8-11\%), no eixo embrionário (15-16 \%) e no escutelo (23-25 \%). O embrião (eixo embrionário e escutelo) é rico em lipídios, porém compreende apenas cerca de $3 \%$ do peso do grão. A maior parte dos lipídios está no germe e no endosperma (Youngs, 1978).

Youngs et al. (1977) realizaram minuciosa investigação sobre a composição e distribuição dos lipídios em dois cultivares de aveia (Dal e Froker). Para obtenção das frações lipídicas foram utilizados os métodos de Soxhlet, com éter dietílico e os extratos foram extraídos novamente com $n$-butanol saturado em água. Através de cromatografia em camada delgada (CCD) a fração lipídica foi separada e caracterizada com obtenção de doze classes, sendo a maior porcentagem de triglicerídios (41\%) seguida da presença de glicerídios tais como monogalactosilglicerídios e digalactosilglicerídios (11\%) e de fosfolipídios, como fosfatidilcolina, fosfatidiletanolamina e lisofosfatidiletanolamina (10 $\%$ no total). Outros compostos encontrados em menor escala foram ácidos graxos livres (5 \%), diglicerídios (3 \%) e esteróis (1 \%). 
Em todos os estudos, os ácidos graxos palmítico, oléico e linoléico são os principais representantes, somando cerca de $95 \%$ do total. Os ácidos mirístico, esteárico e linolênico ocupam a porção restante (Pedó, 2000).

\subsection{Deterioração lipídica}

Sabe-se que os lipídios são compostos instáveis, principalmente quando expostos à luz, calor e oxigênio. A estabilidade oxidativa é, com certeza, um importante parâmetro de qualidade de gorduras animais e óleos vegetais (Laubli \& Bruttel, 1986). Os principais componentes que produzem o “off-flavour” ou odor desagradável característico de um óleo oxidado são os triglicerídios e os fosfolipídios como a lecitina, fosfatidiletanolamina e fosfatidilserina em cujas estruturas existem ácidos graxos insaturados (Hamilton, 1994).

A oxidação de lipídios é, indubitavelmente, a maior causa de deterioração de óleos e gorduras que leva à formação de sabores e aromas desagradáveis nos produtos. O processo de oxidação pode resultar em compostos de ranço que alteram as características organolépticas de produtos, tornando-os inaceitáveis para o consumidor e podendo causar outros efeitos de degradação, como escurecimento ou alteração da coloração, destruição de vitaminas, perdas nutricionais e polimerização (Sherwin, 1978; Shahidi, 1995).

Robards et al. (1988) citam alguns fatores que desencadeiam o início da deterioração oxidativa da fração lipídica: tipo e concentração de antioxidante, grau de insaturação do óleo, oxigênio disponível, área superficial exposta, conteúdo de água, temperatura e grau de exposição à luz.

Existem dois tipos de deterioração, a hidrolítica e a oxidativa. A primeira refere-se à reação de hidrólise com a produção de ácidos graxos livres. Esta reação pode ser catalisada por lipases presentes em grãos oleaginosos e alimentos, ou produzidas por microorganismos (Fennema, 1992). Já a deterioração oxidativa é, do ponto de vista da qualidade de óleos e gorduras, a mais importante e a que ocorre na maioria dos alimentos. 
A oxidação de lipídios pode ser iniciada por espécies endógenas $\left(\mathrm{H}_{2} \mathrm{O}_{2}\right.$, $\mathrm{ROOH})$ e radicais ( $\mathrm{O}_{2}$, ROO', ${ }^{\circ} \mathrm{OH}, \mathrm{GS}$ ) $)$ ou por espécies exógenas $\left({ }^{1} \mathrm{O}_{2}, \mathrm{O}_{3}\right)$, radicais (NOx, $\mathrm{SO}_{3}{ }^{-}$) e agentes (UV, radiação ionizante e calor) (Simic et al., 1992). Alguns metais são conhecidos por serem pró-oxidantes mesmo quando há presença de traços; calor também é um grande acelerador da oxidação, especialmente em temperaturas acima de $60^{\circ} \mathrm{C}$, a partir da qual foi estimado que para cada acréscimo de temperatura da ordem de $15^{\circ} \mathrm{C}$, a velocidade da reação de oxidação dobra (Sherwin, 1978).

A autoxidação dos ácidos graxos insaturados ocorre basicamente em três etapas: iniciação, propagação e terminação. A fase de iniciação começa quando o átomo de hidrogênio adjacente à dupla ligação do ácido graxo é liberado por ação de luz, calor ou íons metálicos. Forma-se um radical livre que reage com o oxigênio atmosférico para formar um radical peróxido instável, o qual pode tornar a liberar um ácido graxo insaturado para a formação de um hidroperóxido e de um novo radical livre. Esse novo radical livre prossegue a oxidação e contribui para as reações em cadeia (Shahidi, 1995; Simic et al., 1992; Gray, 1978). O mecanismo da formação de peróxidos é mostrado na Figura 4.

Durante os processos de extração, cuidados com a prevenção da oxidação dos lipídios devem ser tomados, pois pode haver comprometimento na identificação dos componentes da fração lipídica. 


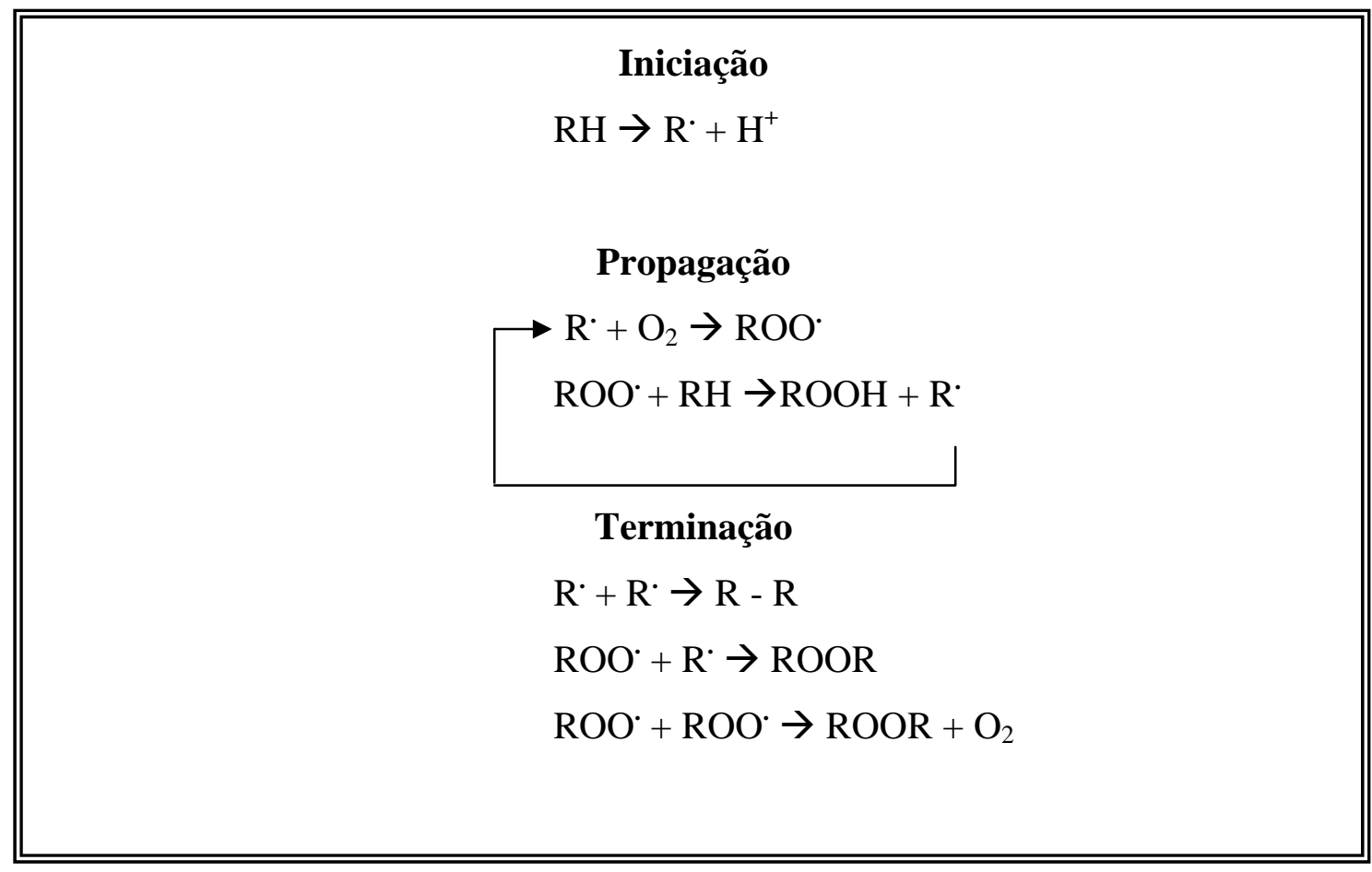

Figura 4 - Mecanismo de formação de hidroperóxidos através da autoxidação

Fonte: Farmer et al. (1942)

$\mathrm{RH}=$ ácido graxo

$\mathrm{R}^{*}=$ radical de ácido graxo

$\mathrm{ROO}^{*}=$ radical peróxido

$\mathrm{ROOH}=$ hidroperóxido

No estágio final, os hidroperóxidos formados em quantidades cada vez maiores, decompõem-se em substâncias de menor peso molecular (aldeídos, hidrocarbonetos, cetonas, álcoois e ácidos), os reais responsáveis pela inaceitabilidade dos produtos devido ao ranço. A reação de oxidação é ainda responsável pela formação de polímeros (compostos de alto peso molecular) que alteram a qualidade dos óleos e gorduras (Gunstone \& Norris, 1983). 


\subsubsection{Deterioração lipídica em cereais}

A deterioração lipídica, com resultante perda da qualidade e aceitabilidade, pode ocorrer em produtos de cereais devido a reações de degradação nos vários estágios no decorrer da cadeia que compreende a colheita do grão até o armazenamento, através de diferentes operações neste processo, chegando até o produto final. Em geral, a lipólise é um grande problema em produtos de cereais, pois nesses alimentos os tecidos contêm as enzimas envolvidas na degradação lipídica catalisada pela enzima conhecida como lipase. Como ocorre em qualquer outro tipo de alimento, a deterioração em cereais pode ser devido às reações de degradação hidrolítica ou oxidativa, e geralmente, por ambas. Em algumas situações a lipólise pode predispor o alimento a uma subseqüente deterioração oxidativa (Galliard, 1994).

A estabilidade dos cereais secos é afetada por quatro principais formas de deterioração: ganho de umidade, processo oxidativo, perda de vitaminas e danos mecânicos. A deterioração oxidativa é tida como a mais importante porque a atividade de água dos cereais desidratados está abaixo da camada monomolecular, paralisando todos os outros tipos de reações deteriorativas e porque os grãos usados no preparo dos produtos de aveia normalmente apresentam alta proporção de ácidos graxos insaturados, condição para a ocorrência da oxidação (White, 1995).

Na lipólise, os ácidos graxos são liberados dos triglicerídios pela ação de enzimas presentes naturalmente no grão (lipases), adicionadas intencionalmente ou por enzimas de microrganismos contaminantes. Resultados finais desta hidrólise são o sabor desagradável, aumento da acidez, o aumento da susceptibilidade dos ácidos graxos às reações de oxidação e as alterações de propriedades funcionais (Gutkoski, 2000).

Já a rancidez oxidativa resulta da reação entre ácidos graxos insaturados e o oxigênio atmosférico, catalisada por um grande número de agentes, normalmente enquadrados em dois grandes grupos, os enzimáticos e os não enzimáticos ou químicos (Galliard, 1994).

Na rancidez oxidativa enzimática, as lipoxigenases e outras enzimas catalisam reações entre os ácidos graxos insaturados e o oxigênio molecular, produzindo 
hidroperóxidos. A deterioração oxidativa não enzimática é catalisada por metais, íons, e irradiação, que promovem a reação dos ácidos graxos com o oxigênio molecular. Esta reação, embora ocorra nos lipídios de origem vegetal, tem sua intensidade diminuída devido aos antioxidantes naturais (Gutkoski, 2000).

Existe uma larga faixa de componentes fenólicos na aveia, incluindo ésteres ligados a glicosídios, ésteres ligados a gliceróis conjugados e ésteres ligados a grupos alquil conjugados. Lipídios polares extraídos da aveia têm apresentado altos níveis de atividade antioxidante, sendo que foram identificados ácidos de cadeia longa como os mono e diésteres do ácido caféico e ácido ferúlico. A atividade antioxidante é medida através da habilidade com que o antioxidante tem de reagir com radicais livres e quebrar a cadeia de propagação cíclica associada à formação dos peróxidos (Gray et al., 2000).

Além dos compostos fenólicos, outros componentes também possuem propriedades antioxidantes na aveia, incluindo os tocóis e esteróis (Peterson et al., 2000).

\subsubsection{Qualidade dos grãos de aveia}

Como a hidrólise lipídica ocorre mais rapidamente que a da proteína ou carboidratos, a acidez e o teor de ácidos graxos livres são indicadores sensíveis de deterioração incipiente de grãos armazenados e seus produtos (Christensen \& Kaufmann, 1974). Os métodos de determinação normalmente envolvem a obtenção de amostra, óleo ou farinha do produto em estudo, preparo e titulação com uma base de normalidade conhecida, sendo os valores expressos em porcentagem de ácidos graxos livres (acidez) ou expressos em mg de hidróxido de potássio por grama de amostra (índice de acidez).

A acidez da aveia aumenta rapidamente após a desintegração do grão. Sahasrabudhe (1982) avaliou a produção de ácidos graxos livres em cariopses de aveia, incubadas a $38{ }^{\circ} \mathrm{C}$ por 30 minutos, e com diferentes níveis de injúrias. Na cariopse intacta, não foi observado o desenvolvimento de acidez. A cariopse dividida ao meio 
apresentou aumento na acidez para 4,5 mg de $\mathrm{KOH} / \mathrm{g}$ de amostra. Na cariopse completamente moída, o autor verificou aumento para 12,3 mg de $\mathrm{KOH} / \mathrm{g}$ de amostra.

Os métodos disponíveis para acompanhar a deterioração oxidativa em alimentos e sistemas biológicos, normalmente, determinam as alterações primárias e secundárias da oxidação (Shahidi, 1995). As alterações primárias podem ser monitoradas através da redução de ácidos graxos insaturados, aumentado consumo de oxigênio ou ganho de peso, índice de peróxidos e análise de dienos e trienos conjugados.

Surpreendentemente, Welch (1977) não detectou peróxidos em grãos de aveia após secagem a diferentes temperaturas (50, 80, e $100{ }^{\circ} \mathrm{C}$ ) e armazenamento nas umidades de 12, 14, 16 e 18 \% por 330 dias. Embora a deterioração oxidativa tenha sido relatada em produtos processados, o autor afirma não ter encontrado evidências de que a mesma se desenvolva em grãos de aveia intactos.

\subsubsection{Oxidação lipídica em carnes e produtos cárneos}

\subsubsection{Peito de frango}

A oxidação lipídica é o principal processo pelo qual ocorre a perda da qualidade da carne e seus produtos, depois da deterioração microbiana (Gray et al., 1996). Os danos causados aos lipídios podem ser acentuados imediatamente no pósabate e, em particular, durante a manipulação, processamento, armazenamento e cozimento (Morrisey et al., 1998).

Segundo Andersen et al. (2003), a oxidação lipídica em carnes, envolve os lipídios polinsaturados das membranas celulares e está relacionada também com a oxidação dos pigmentos das carnes, provocando perda da cor. As alterações bioquímicas que acompanham a conversão do músculo em carne oferecem condições favoráveis para que ocorra a oxidação na fração mais insaturada de fosfolipídios nas membranas subcelulares, onde o balanço entre os fatores pró-oxidativos e a capacidade antioxidativa não está controlado, favorecendo a oxidação lipídica (Morrisey et al., 1998). 
Durante o processo de conversão de músculo em carne, mudanças bioquímicas que acompanham o metabolismo post mortem, promovem condições para que o processo de oxidação se instale. Estas mudanças favorecem o desenvolvimento da oxidação na fração fosfolipídica insaturada das membranas subcelulares, uma vez que é improvável que os mecanismos de defesa das células do animal vivo ainda funcionem perfeitamente após o abate (Gray et al., 1996; Morrissey et al., 1998).

O processo de deterioração inicia logo após a morte do animal e aumenta de intensidade até que a carne se torne inaceitável ao consumo. Morrisey et al. (1998) enumeraram algumas alterações pós-abate que predispõem o músculo à oxidação: 1) atordoamento e sangria, cessação da circulação sangüínea; 2) cessação rápida da circulação de nutrientes; 3) aceleração do metabolismo anaeróbico - acúmulo de ácido láctico, queda do pH a 5,5; 4) destruição parcial do compartimento celular; 5) ocorrência das reações em cadeia catalisadas pelo ferro; 6) início da oxidação na membrana lipídica.

Os hidroperóxidos, produtos primários da oxidação lipídica, não possuem um odor desagradável, mas, na seqüência das reações, serão decompostos a uma variedade de produtos secundários não-voláteis e voláteis, estes sim, com odor pronunciado (Mottram, 1994). Drumm \& Spanier (1991) concluíram que os aldeídos são os principais contribuintes para a perda do sabor ideal nas carnes, visto que sua formação durante a oxidação lipídica é rápida. De uma maneira geral, o odor desenvolvido nas carnes armazenadas sob refrigeração pode ser atribuído mais ao mascaramento do seu aroma natural devido ao aumento do conteúdo de odores desagradáveis no material armazenado do que à degradação do aroma original (Gray et al., 1996).

Existem outros fatores que afetam a estabilidade oxidativa em carnes, entre eles, a oxidação dos pigmentos de mioglobina, presentes na fase aquosa do tecido muscular. A mioglobina é um composto protéico hidrossolúvel, que possui um grupo heme em sua estrutura. Este grupo heme, contém um átomo de ferro, o qual está prontamente sujeito a mudanças em seu estado oxidativo $\left(\mathrm{Fe}^{2+} \mathrm{e} \mathrm{Fe}^{3+}\right.$ ) (Ranken, 1994).

Após a morte do músculo, o transporte de oxigênio realizado pela mioglobina, é responsável pela manutenção da cor vermelha brilhante da carne. A mioglobina pode 
carregar ou liberar o oxigênio somente quando o ferro do grupo heme estiver no estado de $\mathrm{Fe}^{2+}$. Tanto a molécula de mioglobina pode existir na forma oxigenada, ligada a uma molécula de oxigênio, como na forma não oxigenada, sem a presença de uma molécula de oxigênio. A coloração do músculo na primeira forma é o vermelho vivo e, na segunda, um vermelho púrpuro. Se o ferro oxidar-se a $\mathrm{Fe}^{3+}$, o complexo heme se torna insolúvel, a coloração mudará para o marrom e nenhum oxigênio poderá se ligar. Esta forma oxidada é conhecida como metamioglobina (Ranken, 1994).

Diversos estudos têm indicado que a oxidação lipídica em produtos cárneos pode ser efetivamente controlada ou, no mínimo, minimizada pelo uso de antioxidantes fenólicos ou a aplicação de atmosfera controlada, com altas concentrações de dióxido de carbono.

\subsection{Acidez}

O método IUPAC 2.201 (1979) define índice de acidez como o número de miligramas de hidróxido de potássio necessários para neutralizar os ácidos graxos livres em um grama de óleo. A acidez é uma expressão convencional da porcentagem de ácidos graxos livres (AGL) e, de acordo com a natureza do óleo, pode ser expressa em ácido láurico, palmítico ou oléico. De maneira geral, a acidez é expressa em porcentagem de ácido oléico, pois é um ácido graxo presente na maioria dos alimentos e em concentrações apreciáveis. A acidez é calculada através dos resultados obtidos na determinação do índice de acidez, seja pelo método do indicador, seja pelo método potenciométrico.

Os ácidos graxos livres presentes em óleos e gorduras são resultantes da hidrólise de alguns triglicerídios, na ligação éster entre o glicerol e o ácido graxo. A acidez está associada à caracterização do estado de conservação de grãos e de deterioração de óleos e gorduras, por conseguinte a ocorrência de ácidos graxos livres indica a perda da integridade da molécula, antes neutra e totalmente apolar (Mehlenbacher, 1960; Krishnamurty, 1982). 
Como os ácidos graxos são ácidos fracos, é necessário usar uma base forte como hidróxido de sódio ou de potássio para titulá-los. Pelo mesmo motivo, o ponto de equivalência estequiométrica, quando titulados com uma base forte, está no lado alcalino da neutralidade (pH=7) (Baccan et al., 2001). Por isso, a acidez causada pelos ácidos graxos livres é estimada, com hidróxido de sódio ou de potássio em solução alcoólica, usando fenolftaleína como indicador. No Brasil, o álcali é dissolvido em álcool etílico, nos Estados Unidos, em isopropílico, ou em mistura 1:1 de álcool e éter dietílico (Cocks \& van Rede, 1966), devido à insolubilidade de óleo e ácidos graxos na água dos reagentes. No entanto a metodologia apresenta algumas desvantagens: (a) os ácidos graxos são solúveis, mas os triglicerídios não o são em álcool etílico, com isso o aquecimento da mistura e a agitação devem ser suficientes para completa dissolução dos ácidos graxos (deve-se evitar sobreaquecimento); (b) o sistema bifásico formado traz alguns inconvenientes para a visualização do ponto final; (c) agitação exagerada pode introduzir dióxido de carbono da atmosfera e produzir descoloração prematura do indicador.

\subsection{4 Índice de peróxido}

A quantificação ou estimativa do teor de peróxidos (ou hidroperóxidos) é baseada na habilidade do peróxido liberar o iodo do iodeto de potássio em solução de ácido acético glacial. É o método mais usado para determinar o grau de oxidação. O valor de peróxido é a medida do teor de oxigênio reativo expresso em termos de miliequivalentes de oxigênio por 1.000 g ou como milimoles de peróxido por quilo de matéria graxa (1 milimol = 2 miliequivalentes) (Mehlenbacher, 1960). 
A reação iodométrica que ocorre é a seguinte:

$$
\begin{aligned}
& 2 \mathrm{KI}+2 \mathrm{CH}_{3} \mathrm{COOH} \rightarrow 2 \mathrm{HI}+2 \mathrm{CH}_{3} \mathrm{COO}-\mathrm{K}^{+} \\
& \mathrm{ROOH}+2 \mathrm{HI} \rightarrow \mathrm{ROH}+\mathrm{H}_{2} \mathrm{O}+\mathrm{I}_{2} \\
& \mathrm{I}_{2}+2 \mathrm{Na}_{2} \mathrm{~S}_{2} \mathrm{O}_{3} \rightarrow \mathrm{Na}_{2} \mathrm{~S}_{4} \mathrm{O}_{6}+2 \mathrm{NaI}
\end{aligned}
$$

Pelas etapas da reação (1) verifica-se que cada mol de ROOH reage com 2 moles de iodeto para produzir $1 \mathrm{~mol}$ de $\mathrm{I}_{2}$ que, por sua vez, irá reagir com 2 moles de $\mathrm{Na}_{2} \mathrm{~S}_{2} \mathrm{O}_{3}$, produzindo tetrationato de sódio.

Os métodos volumétricos que envolvem a oxidação de íons iodeto (iodometria) ou a redução do iodo (iodimetria) são baseados na semi-reação (2):

$$
\mathrm{I}_{2}+2 \mathrm{e}^{-} \leftrightarrow 2 \mathrm{I}^{-}
$$

As substâncias que possuem potenciais de redução menores do que o do sistema $\mathrm{I}_{2} / \mathrm{I}^{-}$são oxidadas pelo iodo, portanto podem ser tituladas com uma soluçãopadrão desta substância (iodimetria), conforme a reação (3):

$$
2 \mathrm{~S}_{2} \mathrm{O}_{3}{ }^{2-}+\mathrm{I}_{2} \leftrightarrow \mathrm{S}_{4} \mathrm{O}_{6}{ }^{2-}+2 \mathrm{I}^{-}
$$

Os íons iodeto exercem uma ação redutora sobre sistemas fortemente oxidantes, com a formação de quantidade equivalente de iodo. O iodo liberado é então titulado com uma solução-padrão de tiossulfato de sódio (iodometria) (Baccan et al., 2001).

Esse método iodométrico apresenta algumas fontes de erro, as quais podem ser: (a) absorção do iodo nas ligações insaturadas da matéria graxa; (b) liberação do iodo do iodeto de potássio pelo oxigênio presente na solução no momento da agitação; (c) variação no peso da amostra; (d) variação nas condições de reação, tais como temperatura e tempo; (e) tipo e marca do solvente usado; (f) constituição e reatividade dos peróxidos que estão sendo titulados. Cocks \& van Rede (1966) salientaram a 
importância de se conhecer a história imediatamente anterior da amostra que está sob teste, pois dessa maneira a compreensão do resultado do índice de peróxido é melhor.

Os hidroperóxidos são produtos primários da oxidação e sua taxa inicial de formação normalmente excede a de decomposição, porém isto é revertido nos últimos estágios. O método Cd 8b-90 da American Oil Chemists’ Society (AOCS, 1995) é aplicável para todos os óleos e gorduras, é empírico e qualquer variação no procedimento pode afetar os resultados. Além disso, o método é falho na quantificação de baixas quantidades de peróxidos devido às dificuldades em determinar o ponto final de titulação. Para aumentar a sensibilidade do método, foi proposta a substituição da etapa de titulação por técnica eletroquímica, na qual o iodo liberado é reduzido por eletrodo de platina, mantido em potencial constante (Shahidi, 1995).

A determinação do ponto final em uma titulação iodométrica é verificada com a presença de uma solução aquosa de amido como indicador, pois proporciona uma detecção mais sensível do ponto final. O amido é uma substância formada principalmente por dois constituintes macromoleculares lineares, chamados amilose ( $\beta$ amilose) e amilopectina ( $\alpha$ - amilose), com conformações helicoidais. Estas substâncias formam complexos de adsorção (complexo tipo transferência de carga) com o iodo na forma de íons $\mathrm{I}_{3}{ }^{-}$, conferindo à solução uma coloração azul intensa, como indicado pela reação (4):

$$
\begin{aligned}
& \text { Amilose ( } \beta \text { - amilose })+\mathrm{I}_{3}^{-} \leftrightarrow \text { cor azul intensa } \\
& \text { Amilopectina ( } \alpha \text { - amilose) }+\mathrm{I}_{3}^{-} \leftrightarrow \text { cor violácea }
\end{aligned}
$$

A sensibilidade da reação do amido com o iodo diminui com o aumento da temperatura e na presença de álcool etílico e/ou metílico (Baccan et al., 2001). 


\section{MATERIAL E MÉTODOS}

\subsection{Matérias-primas}

Os materiais utilizados neste trabalho foram escolhidos devido à disponibilidade dos mesmos no Laboratório de Óleos e Gorduras do Departamento de Agroindústria, Alimentos e Nutrição da ESALQ/USP, visto terem sido utilizados em experimentos que não objetivavam um aprofundamento no estudo das metodologias de extração dos lipídios, porém necessitavam dessa determinação.

Foram utilizadas amostras comerciais de aveia em flocos da marca Quaker ${ }^{\circledR}$ e peito de frango congelado. A aveia em flocos estava embalada dentro de caixas de papelão e em sacos de polietileno, armazenadas à temperatura ambiente.

Os peitos de frango utilizados foram obtidos de aves criadas no Departamento de Produção Animal da ESALQ/USP. As aves consumiram dieta contendo basicamente milho (60 \%), farelo de soja (32 \%) e óleo de vísceras de aves (4 \%), além dos suplementos nutricionais necessários à formulação da ração. Essas aves foram abatidas com 47 dias de idade, sofrendo evisceração e conseqüente separação das partes (peito, coxas e sobrecoxas) e após o abate foram embaladas em sacos plásticos do tipo "zip-loc” e armazenadas à temperatura de $-18^{\circ} \mathrm{C}$, até sua utilização nas extrações.

\subsection{Métodos de extração da fração lipídica nas amostras selecionadas}

Todos os solventes utilizados nas extrações e análises foram de qualidade p.a., das marcas Synth e Nuclear. 
Empregaram-se os métodos de Soxhlet, segundo método IUPAC 1.122 (1979), com $n$-hexano (faixa de ebulição $68-70{ }^{\circ} \mathrm{C}$ ) como solvente de extração, avaliando-se neste método, a variável "tempo de extração". O n-hexano foi escolhido, ao invés do éter de petróleo, por ser menos volátil, menos oneroso e apresentar a mesma eficiência. Após alguns testes preliminares, foi fixada a velocidade/quantidade de sifonagens do solvente, na câmara de extração. Padronizou-se entre 6 e 8 sifonagens por hora à temperatura constante e com fluxo de gotejamento entre 150 e 200 gotas por segundo, que demonstraram ser completamente eficientes para o procedimento da extração. As extrações foram realizadas em dois períodos de tempo distintos (4 e 8 horas), com o objetivo de avaliar a eficiência e rendimento do método, bem como a otimização do mesmo no que diz respeito a um menor desperdício de água (dos condensadores) e energia elétrica. Além da metodologia de Soxhlet (1879), foram empregados os métodos de Folch et al. (1957), com clorofórmio e metanol na proporção de 2:1 (v/v); de Bligh \& Dyer (1959), com clorofórmio, metanol e água na proporção de 1:2:0,8 (v/v) e de Hara \& Radin (1978), com $n$-hexano e isopropanol na proporção de 3:2 (v/v), em cujas miscelas foram determinadas a acidez e o índice de peróxido. A análise espectrofotométrica na faixa do ultravioleta foi realizada somente nas miscelas obtidas através da metodologia de Hara \& Radin (1978), modificada por Evangelista (1996), na qual a mistura $n$-hexano-isopropanol foi substituída pela de isoctanoisopropanol.

Para as amostras de peito de frango, os quatro métodos de extração foram padronizados após vários testes preliminares no laboratório. Entretanto, para a aveia em flocos, os métodos de Folch et al. (1957) e Bligh \& Dyer (1959) sofreram algumas modificações a fim de se atingir um maior rendimento ao final do processo.

\subsection{Aveia em flocos}

Para as extrações, as amostras de aveia em flocos foram previamente trituradas em micro moinho Tecnal do tipo Willie (TE - 048) a fim de se obter uma granulometria homogênea e uma maior superfície de contato com os solventes usados para a extração 
do óleo. A granulometria média (66,7 \% retido) da amostra triturada foi de 0,595 mm, verificada em jogo de peneiras Granutest $n^{\circ} 30$.

A composição bromatológica (umidade, proteína e cinza) foi determinada segundo as metodologias da AOAC (1995), tanto para a aveia em flocos, quanto para o peito de frango. A umidade foi determinada através dos métodos gravimétricos 925.10, para a aveia em flocos e 950.46 para o peito de frango, em estufa a $105^{\circ} \mathrm{C}$ até peso constante. O teor de cinza foi aferido pelos métodos gravimétricos 923.03 (aveia em flocos) e 920.153 (peito de frango)em mufla a $550{ }^{\circ} \mathrm{C}$ e incineração da matéria orgânica em bico de Bunsen. A determinação de teor de proteína bruta, isto é, de nitrogênio total foi realizada através dos métodos micro-Kjeldahl 960.85, para a aveia em flocos e 928.08, para o peito de frango, com digestão em bloco digestor seguido da destilação e posterior titulação com ácido sulfúrico 0,02 N e com conversão a proteína bruta através do fator 6,25. A fração lipídica foi quantificada em extrator de Soxhlet, utilizando-se o n-hexano como solvente de extração conforme o método IUPAC 1.122 (1979).

\subsubsection{Método de Soxhlet}

Foram pesados $5 \mathrm{~g}$ da amostra em vidro de relógio. O material foi transferido para o cartucho de extração, com auxílio de um pedaço de algodão desengordurado e levemente umedecido de $n$-hexano. A amostra foi coberta, no cartucho, com este pedaço de algodão. As extrações foram realizadas em períodos de 4 e 8 horas, em aparelho de Soxhlet com $n$-hexano como solvente de extração. Nestes períodos de tempo, foram observados os tempos de 6 e 8 sifonagens do solvente por hora na câmara de extração. A temperatura foi mantida constante no aparelho extrator, dentro da faixa de ebulição do $n$ hexano $\left(68-70{ }^{\circ} \mathrm{C}\right)$. Balões de $250 \mathrm{~mL}$ foram utilizados no aparato e o volume de solvente usado para cada extração foi de aproximadamente $170 \mathrm{~mL}$. Após o término do período de extração e arrefecimento da miscela, foram retiradas alíquotas de $3 \mathrm{~mL}$ para análises de lipídios totais, acidez e índice de peróxido. O restante da miscela foi concentrado a vácuo em evaporador rotativo da marca Marconi (modelo TE - 120) a 40$45^{\circ} \mathrm{C}$, sendo o solvente recuperado. 


\subsubsection{Método de Folch et al.}

O método de Folch et al. (1957), utilizado neste trabalho, seguiu algumas modificações propostas por Christie (1982). Além destas modificações, outras foram efetuadas para adequação da aveia em flocos à metodologia, pois este procedimento foi desenvolvido originalmente para extração de lipídios de tecidos animais. Foram pesados 5 g da amostra em erlenmeyer de $250 \mathrm{~mL}$ com tampa de vidro, adicionando-se inicialmente $25 \mathrm{~mL}$ de metanol. A homogeneização foi realizada por cerca de 5 minutos em mesa agitadora da marca Nova Técnica (modelo NT 145), com agitação vigorosa. Após esta etapa, foram adicionados $50 \mathrm{~mL}$ de clorofórmio e a agitação foi efetuada por mais 10 minutos. A mistura foi filtrada a vácuo, sendo o resíduo sólido ressuspendido em 30 mL da solução de clorofórmio-metanol 2:1 (v/v) e homogeneizado por 5 minutos. Após filtração, o sólido foi lavado mais uma vez com 50 mL de clorofórmio e com 25 $\mathrm{mL}$ de metanol. Os filtrados combinados foram transferidos para um funil de separação e, 1/4 do volume total foi adicionado de uma solução de $\mathrm{KCl}$ 0,88 \%. A mistura foi agitada vigorosamente e levada ao repouso. A fase inferior, ou seja, o extrato de clorofórmio contendo os lipídios, foi removida para um erlenmeyer de $125 \mathrm{~mL}$, sendo recolhida em papel filtro com sulfato de sódio anidro (remoção de traços de água). Foram retiradas alíquotas de $3 \mathrm{~mL}$ para análises de lipídios totais, acidez e índice de peróxido. O restante da miscela foi concentrado a vácuo em evaporador rotativo da marca Marconi (modelo TE - 120) a $40-45^{\circ} \mathrm{C}$, sendo o solvente recuperado.

\subsubsection{Método de Bligh \& Dyer}

Para a extração dos lipídios, foram pesados aproximadamente 10 g de cada amostra. Em um erlenmeyer de $250 \mathrm{~mL}$ foram adicionados $50 \mathrm{~mL}$ de metanol, $25 \mathrm{~mL}$ de clorofórmio e $10 \mathrm{~mL}$ de água cujo volume é dependente da quantidade de água tissular da amostra (umidade de 11,88 \%). O erlenmeyer foi tampado e colocado em mesa agitadora da marca Nova Técnica (modelo NT 145) por 20 minutos. Em seguida, foram adicionados mais $25 \mathrm{~mL}$ de clorofórmio e $25 \mathrm{~mL}$ de solução de sulfato de sódio 1,5 \%. 
Agitou-se a mistura por mais 2 minutos. A solução com a amostra foi transferida para um funil de separação, onde ocorreu a formação do sistema bifásico. A camada inferior, ou seja, a fase orgânica rica em clorofórmio e que contém os lipídios, foi removida para um erlenmeyer de 125 mL. Essa miscela foi filtrada através de um funil pequeno com papel de filtro contendo sulfato de sódio anidro, sendo, em seguida, retiradas alíquotas de $3 \mathrm{~mL}$ para análises de lipídios totais, acidez e índice de peróxido. O restante da miscela foi concentrado a vácuo em evaporador rotativo da marca Marconi (modelo TE 120) a $40-45^{\circ} \mathrm{C}$, sendo o solvente recuperado.

\subsubsection{Método de Hara \& Radin}

A extração foi realizada pela adição de $40 \mathrm{~mL}$ de isopropanol a $10 \mathrm{~g}$ de amostra pesadas em erlenmeyer de $250 \mathrm{~mL}$ com tampa de vidro com homogeneização em mesa agitadora da marca Nova Técnica (modelo NT 145) por 2 minutos. Seguiu-se a imediata adição de $60 \mathrm{~mL}$ de $n$-hexano com homogeneização na mesma mesa agitadora por também 2 minutos. Filtrou-se a vácuo, ressuspendendo a amostra decantada no fundo do erlenmeyer, em $25 \mathrm{~mL}$ de mistura $n$-hexano-isopropanol 3:2 (v/v) e filtrandose novamente. O filtrado foi transferido para um funil de extração de $250 \mathrm{~mL}$ ao qual se adicionou $60 \mathrm{~mL}$ de solução de sulfato de sódio (preparada na concentração de $1 \mathrm{~g}$ de $\mathrm{Na}_{2} \mathrm{SO}_{4}$ anidro/15 mL de solução). Procedeu-se agitação rigorosa até repouso completo para melhor visualização da separação das fases. Retirou-se uma alíquota de $3 \mathrm{~mL}$ da fase superior (miscela rica em $n$-hexano) com pipeta volumétrica, que foi transferida para erlenmeyer de $50 \mathrm{~mL}$ previamente tarado para determinação do conteúdo de óleo. As outras alíquotas foram usadas na determinação da acidez e do índice de peróxido.

\subsection{Peito de frango}

Para as extrações, as amostras de peito de frango foram previamente descongeladas em refrigerador e trituradas em moedor de carne da marca Vicris, modelo 
5068-85, contendo um disco com furos de $5 \mathrm{~mm}$ de diâmetro. A composição bromatológica foi determinada conforme descrito no item 3.3.

\subsubsection{Método de Soxhlet}

Para extração da fração lipídica das amostras de tecidos animais (peito de frango), foi aplicado o mesmo procedimento que da aveia em flocos, descrito em 3.3.1.

\subsubsection{Método de Folch et al.}

Foi usada a mesma técnica proposta por Christie (1982), adaptada de Folch et al. (1957), citada em 3.3.2, com algumas modificações. Foram pesados 5 g da amostra em erlenmeyer de $250 \mathrm{~mL}$ com tampa de vidro, adicionando-se inicialmente $25 \mathrm{~mL}$ de metanol. A homogeneização, desta vez, foi realizada por cerca de 1 minuto em mesa agitadora da marca Nova Técnica (modelo NT 145), com agitação vigorosa. Após esta etapa, foram adicionados $50 \mathrm{~mL}$ de clorofórmio e a agitação efetuada por apenas mais 2 minutos.

O procedimento seguido a partir desta etapa foi o mesmo que em 3.3.2.

\subsubsection{Método de Bligh \& Dyer}

Empregou-se o método de Bligh \& Dyer (1959), seguindo as modificações propostas por Christie (1982) e Smedes \& Thomasen (1996). Pesou-se cerca de $10 \mathrm{~g}$ da amostra úmida (umidade de 73,82 \%) e homogeneizou-se o tecido por 4 minutos em erlenmeyer de $250 \mathrm{~mL}$ dotado de tampa de vidro, com uma mistura de solvente consistindo de $10 \mathrm{~mL}$ de clorofórmio e $20 \mathrm{~mL}$ de metanol. Após completa homogeneização, uma única fase foi obtida e procedeu-se a adição de mais $10 \mathrm{~mL}$ de clorofórmio, seguida de agitação por 1 minuto. Filtrou-se a mistura a vácuo e o resíduo tissular foi re-homogeneizado com $10 \mathrm{~mL}$ de clorofórmio, objetivando um maior rendimento de óleo extraído do tecido. Os filtrados foram combinados e transferidos 
para funil de separação de $250 \mathrm{~mL}$, sendo agitado vigorosamente após adição de $10 \mathrm{~mL}$ de $\mathrm{KCl}$ 0,88 \%. Neste momento formou-se um sistema bifásico, com a fase superior composta de metanol, água e não-lipídios e a fase inferior, com clorofórmio, contendo os lipídios extraídos. A fase orgânica foi recolhida e filtrada (adicionou-se sulfato de sódio anidro sobre papel filtro) antes de o solvente ser recuperado no evaporador rotativo, retirando-se alíquotas de $3 \mathrm{~mL}$ para análises quanti e qualitativas.

\subsubsection{Método de Hara \& Radin}

Foi seguido o mesmo procedimento aplicado para a aveia em flocos, apresentado em 3.3.4.

\subsection{Análises físico-químicas}

Para verificação da qualidade da fração lipídica obtida, foram realizadas as análises de acidez e índice de peróxido. As determinações foram baseadas no teor lipídico das miscelas empregadas em volume tal que garantissem uma massa em gramas mínima para a ocorrência da reação e conseqüente confiabilidade no resultado da análise e sua repetibilidade.

\subsubsection{Acidez}

O teor de ácidos graxos livres (AGL) das frações lipídicas foi determinado através do método AOCS Ca 5a - 40 (1997), modificado para análise direta na alíquota (miscela). Retiraram-se alíquotas de $3 \mathrm{~mL}$ (triplicata) de miscela, contendo em média 0,40 g/mL, adicionando-se algumas gotas de fenolftaleína ( $\pm 1 \mathrm{~mL}$ ) como indicador e efetuando-se a titulação direta com solução padronizada de $\mathrm{NaOH}, 0,1 \mathrm{~N}$. O ponto de viragem foi verificado com auxílio do indicador e o volume gasto indicou a quantidade de ácidos graxos livres, através da fórmula (5): 
onde: $\mathrm{V}=$ volume gasto na titulação da amostra (mL)

$\mathrm{N}=$ normalidade da solução padronizada de $\mathrm{NaOH}$

m = massa de óleo na alíquota (g)

\subsection{2 Índice de peróxido}

A determinação do índice de peróxido das frações lipídicas produzidas pelos quatro métodos utilizados foi realizada através do método AOCS Cd 8b-90 (1997), modificado para análise direta nas alíquotas (miscela). Retiraram-se alíquotas de $3 \mathrm{~mL}$, contendo 0,40 g/mL e estas foram adicionadas de $30 \mathrm{~mL}$ de solução ácido acético glacial/isoctano 3:2 (v/v), 0,5 mL de solução de iodeto de potássio saturada e $30 \mathrm{~mL}$ de água destilada. Titulou-se com solução padronizada de $\mathrm{Na}_{2} \mathrm{~S}_{2} \mathrm{O}_{3}$ 0,01 N e o volume gasto, após adição de solução de amido a $1 \%$, usada como indicador, expressou a concentração de peróxidos em meq $\mathrm{O}_{2} / 1000$ g de óleo calculado através da fórmula (6):

$$
\text { IP }\left(\text { meq } \mathrm{O}_{2} / 1000 \mathrm{~g}\right)=(\mathrm{a}-\mathrm{b}) \times \mathrm{N} \times 1000 / \mathrm{m}
$$

sendo: $\mathrm{a}=$ volume gasto na titulação da amostra $(\mathrm{mL})$

$\mathrm{b}=$ volume gasto na titulação dos reagentes sem amostra $(\mathrm{mL})$

$\mathrm{N}=$ normalidade da solução padronizada de $\mathrm{Na}_{2} \mathrm{~S}_{2} \mathrm{O}_{3}$

$\mathrm{m}$ = massa de óleo na alíquota (g)

\subsection{Teor de óleo das miscelas}

A quantificação dos lipídios totais nas amostras empregadas nas análises de acidez e índice de peróxido foi determinada a partir das alíquotas de $3 \mathrm{~mL}$ cada, dos extratos (miscelas) de $n$-hexano, no caso dos métodos de Soxhlet (1879) e Hara \& Radin 
(1978) e de clorofórmio para as extrações de Folch et al. (1957) e Bligh \& Dyer (1959).

Os solventes foram evaporados em estufa a $105{ }^{\circ} \mathrm{C}$ por 40 minutos. Após resfriamento em dessecador por cerca de 40 minutos, pesou-se o recipiente com óleo, repetindo-se as operações de aquecimento e resfriamento, até peso constante.

\subsection{Análise estatística}

O delineamento experimental adotado foi o de blocos casualizados. Os dados obtidos foram submetidos à análise de variância e as médias foram comparadas entre si pelo teste de Tukey, ( $\mathrm{p}<0,05)$, utilizando-se o programa SAS. 


\section{RESULTADOS E DISCUSSÃO}

\subsection{Avaliação dos métodos aplicados}

Nos últimos anos diversos pesquisadores realizaram trabalhos comparando métodos de extração de lipídios (Fishwick \& Wright, 1977; Hara \& Radin, 1978; Sahasrabudhe \& Smallbone, 1983; Koning et al., 1985; Gunnlaugsdottir \& Ackman, 1993; Undeland et al., 1998 e Iverson et al., 2001) em que o objetivo foi encontrar o método mais eficiente para a obtenção da fração lipídica desejada. Além disso, os trabalhos anteriores também buscaram métodos que não alterassem a qualidade do óleo e que também utilizassem solventes menos tóxicos do que a mistura clorofórmio e metanol (Folch et al., 1957; Bligh \& Dyer, 1959; Hanson \& Olley, 1963). No entanto, devido à alta eficiência que este sistema $\left(\mathrm{CHCl}_{3}\right.$ e $\left.\mathrm{MeOH}\right)$ apresenta na extração de lipídios polares e apolares, nenhum sistema alternativo testado recentemente tem obtido o êxito esperado, ou seja, uma eficiência equivalente ao sistema que utiliza um solvente clorado.

No presente estudo comparativo avaliou-se qual método, dentre os escolhidos, proporcionaria o melhor rendimento, repetibilidade, boa qualidade da fração lipídica, rapidez e economia.

Além das análises realizadas na fração lipídica, foi realizada a determinação dos teores dos macro componentes das amostras de aveia em flocos e peito de frango, apresentados nas Tabelas 1 e 2. 
Tabela 1. Composição bromatológica da aveia em flocos (g/100 g)

\begin{tabular}{lc}
\hline Componentes & \\
\hline Umidade & $11,88 \pm 0,03^{* *}$ \\
Cinza* & $14,67 \pm 0,01$ \\
Lipídios* & $8,75 \pm 0,01$ \\
Proteína Bruta* & $12,34 \pm 0,56$ \\
\hline
\end{tabular}

* Média de 3 repetições na matéria seca

** Desvio padrão da média

Tabela 2. Composição bromatológica do peito de frango (g/100 g)

\begin{tabular}{lc}
\hline Componentes & \\
\hline Umidade & $73,61 \pm 0,19 * *$ \\
Cinza* & $1,12 \pm 0,02$ \\
Lipídios* & $5,91 \pm 0,01$ \\
Proteína Bruta* & $20,92 \pm 0,1$ \\
\hline
\end{tabular}

* Média de 3 repetições na matéria seca

** Desvio padrão da média

Uma importante observação que não deve ser desconsiderada é a de que todos os métodos de extração apresentaram rendimentos satisfatórios e em concordância com a literatura. Os valores de teor de óleo apresentados na Tabela 3 para aveia em flocos (6,61 a 7,71 g/100 g matéria úmida) estão em conformidade com o valor exposto no rótulo do produto aveia em flocos da marca Quaker ${ }^{\circledR}$. A Tabela Brasileira de Composição de Alimentos da Faculdade de Ciências Farmacêuticas (FCF/USP, 2004), o United States Departament of Agriculture (USDA, 2004) e Pedó (2000) também 
apresentam valores de lipídios totais que correspondem aos encontrados experimentalmente. Para o peito de frango a faixa encontrada de 1,40 a 1,65 g/100g mat. úmida, para lipídios totais, conforme a Tabela 4 está em concordância com a Tabela Brasileira de Composição de Alimentos da FCF/USP (2004) e com o USDA (2004).

Tabela 3. Lipídios totais da aveia em flocos

\begin{tabular}{cc}
\hline Metodologia & Lipídios totais (g/100g mat. úmida* $^{*}$ \\
\hline Soxhlet / 4h & $7,70^{\mathbf{a}} \pm 0,014^{* *}$ \\
Soxhlet / 8h & $7,71^{\mathbf{a}} \pm 0,016$ \\
Folch et al. & $6,93^{\mathbf{c}} \pm 0,019$ \\
Bligh \& Dyer & $7,66^{\mathbf{b}} \pm 0,020$ \\
Hara \& Radin & $6,61^{\mathbf{d}} \pm 0,031$ \\
\hline
\end{tabular}

* Os valores com as mesmas letras sobrescritas não diferem entre si, em nível de 5 \% de significância, pelo teste de Tukey

** Desvio padrão da média

O bom rendimento em lipídios totais, em ambas amostras analisadas, proporcionado pelo método de Bligh \& Dyer (1959) pode ser explicado pela ampla faixa de polaridade apresentada pela mistura de solventes utilizada. Clorofórmio e metanol são mais polares que $n$-hexano e isopropanol e, dessa forma, há uma extração eficiente de lipídios polares e apolares. Neste trabalho utilizou-se também a metodologia de Folch et al. (1957) que emprega a mistura clorofórmio e metanol, mas que não obteve uma eficiência tão boa quanto a do método de Bligh \& Dyer (1959), provavelmente devido a perdas significativas nas etapas de lavagens sucessivas, recomendadas pelos autores, para a recuperação dos lipídios durante a extração. Outra desvantagem dessa metodologia é a desconsideração do conteúdo de água tissular no alimento analisado.

A extração de Bligh \& Dyer (1959) pode sofrer algumas alterações, mas é imperativo que a proporção de clorofórmio, metanol e água sejam mantidos, antes 
(1:2:0,8) e após (2:2:1,8) a diluição com os solventes. Estas proporções representam os volumes totais existentes no sistema ternário formado pela mistura dos solventes, e inclui a água tissular do alimento estudado.

Tabela 4. Lipídios totais do peito frango

\begin{tabular}{cc}
\hline Metodologia & Lipídios totais (g/100g mat. úmida* \\
\hline Soxhlet / 4h & $1,55^{\mathbf{b}} \pm 0,013^{* *}$ \\
Soxhlet / 8h & $1,56^{\mathbf{b}} \pm 0,018$ \\
Folch et al. & $1,56^{\mathbf{b}} \pm 0,016$ \\
Bligh \& Dyer & $1,65^{\mathbf{a}} \pm 0,018$ \\
Hara \& Radin & $1,40^{\mathbf{c}} \pm 0,016$ \\
\hline
\end{tabular}

* Os valores com as mesmas letras sobrescritas não diferem entre si, em nível de 5 \% de significância, pelo teste de Tukey

** Desvio padrão da média

A ordem de adição dos solventes no procedimento de Bligh \& Dyer (1959) deve ser observada, pois ela é importante para a cinética da extração. No primeiro passo (adição de clorofórmio e metanol) ocorre a destruição da associação dos constituintes da célula, onde os lipídios estão dissolvidos em um sistema monofásico. Em seguida, são transferidos para a fase orgânica de um sistema bifásico, produzido pela adição de clorofórmio e água.

Smedes \& Thomasen (1996) salientaram duas possibilidades em que o tecido pode interferir no rendimento e eficiência da extração: 1) adsorção dos lipídios; 2) absorção da fase orgânica contendo os lipídios.

Durante o desenvolvimento do experimento, observou-se nas extrações de Folch et al. (1957), Bligh \& Dyer (1959) e Hara \& Radin (1978) que o volume da fase orgânica obtida era inferior ao volume inicialmente adicionado de clorofórmio ou nhexano. A redução da fase orgânica variou entre 5 e 10 \% em relação ao volume total 
adicionado. No entanto, essa subtração não afetou significativamente o rendimento das extrações, pois em alguns procedimentos foi realizada uma segunda etapa de extração, adicionando-se mais clorofórmio ou $n$-hexano.

Os efeitos de adsorção podem ser reduzidos por uma alta solubilidade dos lipídios na fase orgânica ou pela presença de um volume suficiente dessa fase (Smedes \& Thomasen, 1996). No caso deste experimento, a diferença entre as polaridades dos solventes talvez seja o fator mais importante nos diferentes rendimentos de lipídios extraídos pelos métodos aplicados. Quanto maior a polaridade dos solventes utilizados no processo de extração, maior deve ser o rendimento de compostos polares, como por exemplo, os fosfolipídios, os quais estão geralmente presentes nas membranas celulares (lipídios ligados).

Consideradas as vantagens e desvantagens citadas em 2.8, diversos autores têm buscado otimizar o método convencional de Soxhlet (1879), modificando o desenho original do aparato de extração ou o procedimento operacional. A redução no tempo de extração, o menor consumo de energia, menor efeito sobre a da qualidade da fração lipídica e um maior rendimento são algumas das preocupações em relação a essa metodologia secular, porém exaustivamente utilizada até os dias de hoje.

Foram realizadas extrações em vidraria de Soxhlet (1879), aplicando-se dois períodos de tempo, avaliando-se a eficiência dessas variáveis. Nas Tabelas 3 e 4 os valores para o período de $4 \mathrm{~h}$ não diferem significativamente dos valores obtidos para as extrações que se prolongaram por $8 \mathrm{~h}$. Isto foi observado tanto para a aveia em flocos quanto para o peito de frango.

Manirakiza et al. (2001) avaliaram o método de Soxhlet (1879) quanto a sua eficiência, analisando amostras de farinha de peixe, chocolate em pó, ração para aves e leite em pó. Definiram o tempo de duas horas como conveniente para a extração dos lipídios, proporcionando um rendimento satisfatório. Períodos de tempo maiores não apresentaram aumento significativo do material extraído. Entretanto, diferentemente desses pesquisadores, o período de duas horas não foi avaliado durante a realização do experimento, pois alguns extratores utilizados não aqueciam homogeneamente suas 
placas de aquecimento, o que poderia levar a um erro durante a avaliação de um tempo relativamente curto (duas horas) de extração.

Apesar de o método de Bligh \& Dyer (1959) ter apresentado o melhor rendimento dentre os métodos analisados, a metodologia de Soxhlet (1879) rendeu resultados que não ficaram aquém do esperado, ou seja, dos valores encontrados na literatura. É importante salientar que o solvente usado (n-hexano) é apolar e não tem a mesma eficiência para extrair os lipídios ligados (polares) como outros solventes de maior polaridade. No entanto, uma das vantagens deste método é a de que a amostra permanece boa parte do tempo imersa no solvente, ocorrendo sifonagens intermitentes que renovam o líquido constantemente, mantendo cada vez maior o gradiente de concentração de óleo entre solvente e amostra que possibilita a solubilização do óleo. A imersão é uma vantagem em relação à extração que utiliza a vidraria de Butt, pois no caso desse aparelho, deve-se ter o cuidado para que o fluxo de gotejamento seja constante sobre o cartucho, e de, no mínimo, 150 gotas por minuto. Outra vantagem da imersão é a de que o uso do $n$-hexano como solvente, tem sua eficácia aumentada, pois este solvente apolar não tem capacidade de extrair os todos os lipídios mais polares, quando o processo é aplicado em um curto período de tempo. Na extração de Bligh \& Dyer (1959), a amostra também fica imersa em contato com os solventes por um período de tempo que não ultrapassa 15 minutos (agitação), dependendo do tipo de amostra, mas a mistura de solventes utilizada têm a capacidade de extrair um maior número de lipídios polares da amostra analisada.

Testes preliminares foram realizados para a padronização dos períodos de tempo a serem avaliados. Definiu-se que entre seis e oito sifonagens por hora seriam adequadas e que os tempos de quatro e oito horas seriam avaliados no desenvolvimento do experimento. Depois da realização destes testes eventualmente ocorreram algumas variações no número de sifonagens, pois foram utilizados três equipamentos para extração, que diferiram quanto ao grau de aquecimento das placas de cerâmica. Não obstante, essas variações foram desconsideradas, pois não alteraram de maneira significativa o resultado final do experimento. 
Uma característica interessante que o método de Bligh \& Dyer (1959) apresentou durante o experimento foi produzir um rendimento superior aos demais métodos. Este poder de extração foi atribuído, entre outros fatores, ao processo de homogeneização vigorosa aplicado nesta metodologia. O poder de extração também tem íntima relação com o fato de que no método de Bligh \& Dyer (1959) uma quantidade, digamos, insuficiente de metanol e água esteve presente para a remoção dos nãolipídios, os quais são geralmente solubilizados pelos lipídios polares na fase orgânica.

Undeland et al. (1998) confirmaram a eficiência do sistema clorofórmiometanol-água na extração dos lipídios polares do arenque (Clupea harengus), realizando análises de separação e quantificação das classes lipídicas. Esses lipídios polares, na sua maioria fosfolipídios, foram facilmente extraídos dos tecidos devido ao arranjo de bicamadas das membranas, nas quais eles estão situados. Por conta desse arranjo, o qual expõe somente os lipídios polares, é compreensível o porquê da necessidade de solventes polares para extração.

De acordo com Bligh \& Dyer (1959) e Christie (1989), o sistema monofásico, obtido utilizando clorofórmio-metanol-água na proporção de 1:2:0,8 (v/v), possui as propriedades ideais para uma extração eficiente. Esse sistema supera as interações entre os lipídios e o tecido da matriz estudada e também os dissolve prontamente.

A baixa eficiência da mistura alcano-álcool-água para a extração de lipídios polares (fosfolipídios) pode ser explicada por duas razões: a primeira é que a parte polar dessa mistura (isopropanol) é menos polar do que o metanol, o qual constitui a porção polar das metodologias propostas por Folch et al. (1957) e Bligh \& Dyer (1959). No entanto, o método de Hara \& Radin (1978), que utilizou a mistura $n$-hexano-isopropanol, apresentou vantagens como a menor toxidez e a melhor separação das fases (mais rápida) quando da adição do $\mathrm{Na}_{2} \mathrm{SO}_{4}$, na etapa de lavagem, removendo eficientemente os não-lipídios da fase orgânica. A segunda razão é que há também o fato de que a solubilidade dos lipídios polares é menor em solventes hidrocarbonetos, tais como nhexano, do que em clorofórmio (Undeland et al., 1998).

No presente experimento, cada método apresentou vantagens e desvantagens. Com relação ao recolhimento da fase orgânica, o método de Hara \& Radin (1978) foi 
mais conveniente do que os métodos de Bligh \& Dyer (1959) e Folch et al. (1957), pois a fase orgânica foi separada na parte superior do sistema formado, em contraste com os sistemas que utilizam o clorofórmio. Esta vantagem está atrelada ao fato de não haver contaminação dos não-lipídios que estão na fase aquosa do sistema. A respeito da evaporação dos solventes, menos de cinco minutos foram necessários para a evaporação do clorofórmio, ao passo que mais de dez minutos foram necessários para evaporar o $n$ hexano, quando se desejou obter os lipídios totais concentrados. Este maior período de tempo deve ter influenciado o aparecimento de peróxidos nos lipídios produzidos pela extração de Soxhlet (1879), além do aquecimento empregado nesta metodologia para o refluxo do solvente.

\subsection{Análises da qualidade da fração lipídica}

\subsubsection{Acidez e índice de peróxido}

Foram realizadas análises físico-químicas que avaliaram a qualidade da fração lipídica, verificando-se a alteração que o processo de extração poderia, eventualmente, causar no óleo obtido.

Previamente à extração, as amostras de aveia em flocos e peito de frango não sofreram nenhum tipo de tratamento de secagem, pois isso levaria à lesão dos tecidos e também desencadearia o processo de oxidação do óleo. Sendo assim, os alimentos foram analisados na matéria úmida evitando-se maiores danos durante a extração. 
Tabela 5. Ácidos graxos livres (AGL) das frações lipídicas da aveia em flocos extraídas por diferentes métodos

\begin{tabular}{cc}
\hline Metodologia & AGL (\%)* \\
\hline Soxhlet / 4 h & $2,25^{\mathbf{a}} \pm 0,009^{* *}$ \\
Soxhlet / 8 h & $2,24^{\mathbf{a}} \pm 0,026$ \\
Folch et al. & $0,91^{\mathbf{b}} \pm 0,012$ \\
Bligh \& Dyer & $0,91^{\mathbf{b}} \pm 0,010$ \\
Hara \& Radin & $0,92^{\mathbf{b}} \pm 0,008$ \\
\hline
\end{tabular}

* Os valores com as mesmas letras sobrescritas não diferem entre si, em nível de 5 \% de significância, pelo teste de Tukey

** Desvio padrão da média

A análise da acidez dos lípides extraídos da aveia em flocos (Tabela 5) pelo método de Soxhlet (1879) apresentou diferença significativa (2,24 a 2,25 \% AGL) em relação aos outros métodos (0,91 a 0,92 \% AGL), evidenciando, dessa forma, que, embora essa metodologia de extração apresente bons rendimentos, ela não deve ser aplicada quando se deseja utilizar o óleo obtido em análises posteriores.

Conforme a Tabela 6, a acidez aferida na fração lipídica do peito de frango não registrou valores muito elevados, ou seja, os métodos não afetaram severamente o material extraído. Entretanto, ocorreram diferenças nos valores entre as frações lipídicas produzidas pelo método de Soxhlet (1879) (2,58 \% AGL) e as demais metodologias (1,02 a 1,05 \% AGL). Essa diferença pode ser explicada pelo favorecimento da hidrólise dos triglicerídios durante o aquecimento das miscelas por tempo prolongado (4 e 8 horas). 
Tabela 6. Ácidos graxos livres (AGL) das frações lipídicas do peito de frango extraídas por diferentes métodos

\begin{tabular}{cc}
\hline Metodologia & AGL (\%)* \\
\hline Soxhlet / 4 h & $2,58^{\mathbf{a}} \pm 0,007^{* *}$ \\
Soxhlet / 8 h & $2,58^{\mathbf{a}} \pm 0,011$ \\
Folch et al. & $1,02^{\mathbf{b}} \pm 0,008$ \\
Bligh \& Dyer & $1,05^{\mathbf{b}} \pm 0,023$ \\
Hara \& Radin & $1,02^{\mathbf{b}} \pm 0,010$ \\
\hline
\end{tabular}

* Os valores com as mesmas letras sobrescritas não diferem entre si, em nível de 5 \% de significância, pelo teste de Tukey

** Desvio padrão da média

A determinação do estado oxidativo como reflexo da qualidade dos lipídios na matriz original em frações recuperadas após extração de Soxhlet (1879) ou outro método semelhante deve ser evitada (Kates, 1972; Rossel, 1994 e Shahidi \& Wanasundara, 1998), pois configura uma fonte de erro. Peróxidos podem ser formados durante o procedimento já que há aquecimento constante da miscela e a exposição ao oxigênio durante a extração.

No experimento realizado, somente as frações lipídicas obtidas através da extração de Soxhlet apresentaram valores de peróxido, de 3,71 meq $\mathrm{O}_{2} / \mathrm{kg}$ para aveia em flocos e de 4,32 meq $\mathrm{O}_{2} / \mathrm{kg}$ para peito de frango (Tabelas 7 e 8). As frações lipídicas das demais metodologias registraram valores iguais a zero, mostrando que o armazenamento das amostras sob congelamento não afetou a estabilidade oxidativa do óleo e que os métodos de extração a frio não são danosos à qualidade da matéria graxa extraída.

Com base nos dados obtidos nos índices de peróxidos das Tabelas 7 e 8, conclui-se que apesar do óleo da aveia em flocos ser rico em ácidos graxos insaturados, os valores de peróxido (3,70 - 3,71 meq $\left.\mathrm{O}_{2} / 1000 \mathrm{~g}\right)$, utilizando o método de Soxhlet (1879), foram inferiores aos valores obtidos na fração lipídica do peito de frango (4,32 - 
4,32 meq $\mathrm{O}_{2} / 1000 \mathrm{~g}$ ). Uma provável explicação é a presença de antioxidantes naturais (ácidos ferúlico e caféico, tocóis e esteróis, $p$-hidroxibenzóico, $p$-hidroxifenilacético e $p$ cumárico) no óleo da aveia (Peterson, 2001), que, de certa forma, minimizariam a degradação da fração lipídica, já que estes compostos reagem com os radicais livres, evitando a formação de peróxidos.

Tabela 7. Índice de peróxido das frações lipídicas da aveia em flocos extraídas por diferentes métodos

\begin{tabular}{cc}
\hline Metodologia & Índice de peróxido (meq $\left.\mathrm{O}_{2} / \mathrm{kg}\right)^{*}$ \\
\hline Soxhlet / 4 h & $3,71^{\mathbf{a}} \pm 0,014^{* *}$ \\
Soxhlet / 8 h & $3,70^{\mathbf{a}} \pm 0,014$ \\
Folch et al. & $0,00^{\mathbf{b}}$ \\
Bligh \& Dyer & $0,00^{\mathbf{b}}$ \\
Hara \& Radin & $0,00^{\mathbf{b}}$ \\
\hline
\end{tabular}

* Os valores com as mesmas letras sobrescritas não diferem entre si, em nível de 5 \% de significância, pelo teste de Tukey

** Desvio padrão da média

Pino et al. (2002) verificaram a influência de diferentes doses de irradiação na estabilidade oxidativa da aveia em flocos. Foram avaliadas aveias em flocos irradiadas com 3,0; 4,5 e 6,0 kGy, durante um período de 6 meses. Os resultados da absortividade nos comprimentos de onda de $232 \mathrm{~nm}$ e $270 \mathrm{~nm}$ do ultravioleta que refletem a ocorrência da oxidação, através da quantificação dos dienos e trienos conjugados (IUPAC, 1979) das frações lipídicas dos flocos de aveia irradiados ou não, não apresentaram um aumento significativo entre as doses, isto é, não ocorreu aumento na absortividade com o aumento da irradiação. Os valores de absortividade em $232 \mathrm{~nm}$ variaram entre 0,0933 a 0,1050 e entre 0,0445 a 0,0509 em $270 \mathrm{~nm}$. 
Esses resultados serviram de parâmetro para o presente trabalho, sendo que dessa forma não foi necessária a repetição das determinações. Os valores encontrados por Pino et al. (2002) ratificaram a inexistência de peróxidos nas extrações realizadas à temperatura ambiente.

No que diz respeito ao peito de frango, a formação de peróxidos foi, indubitavelmente, causada pelo aquecimento no processo de extração e recuperação do solvente, bem como pela presença de oxigênio no armazenamento e na extração, pois as frações lipídicas produzidas pelos outros métodos não apresentaram peróxidos.

Tabela 8. Índice de peróxido das frações lipídicas do peito de frango extraídas por diferentes métodos

\begin{tabular}{cc}
\hline Metodologia & Índice de peróxido (meq $\left.\mathrm{O}_{2} / \mathrm{kg}\right)^{*}$ \\
\hline Soxhlet / $4 \mathrm{~h}$ & $4,34^{\mathbf{a}} \pm 0,009^{* *}$ \\
Soxhlet / 8 h & $4,32^{\mathbf{a}} \pm 0,019$ \\
Folch et al. & $0,00^{\mathbf{b}}$ \\
Bligh \& Dyer & $0,00^{\mathbf{b}}$ \\
Hara \& Radin & $0,00^{\mathbf{b}}$ \\
\hline
\end{tabular}

* Os valores com as mesmas letras sobrescritas não diferem entre si, em nível de 5 \% de significância, pelo teste de Tukey

** Desvio padrão da média

Some-se a isso, a presença de fosfolipídios contendo ácidos graxos altamente insaturados em produtos cárneos, os quais estão susceptíveis à oxidação, pois estão localizados no interior e nas paredes celulares do tecido gorduroso. Por essa razão os fosfolipídios são os primeiros compostos expostos à oxidação quando as células são lesadas (Ranken, 1994).

Em trabalho realizado concomitantemente no Laboratório de Óleos e Gorduras do Departamento de Agroindústria, Nutrição e Alimentos da ESALQ, Pino et 
al. (2004) avaliaram a estabilidade oxidativa das amostras de peito de frango congelado utilizando o teste do TBA, segundo Tarladgis et al. (1960).

O teste do TBA (ácido 2-tiobarbitúrico) é um método utilizado freqüentemente para detecção da oxidação lipídica, pois este teste revela o nível de aldeídos presentes no óleo. Os aldeídos são produtos de quebra dos peróxidos (ou hidroperóxidos) e o ácido 2-tiobarbitúrico reage especificamente com o malonaldeído, resultando em uma solução colorida que pode ser determinada espectrofotometricamente (Rossel, 1994).

Produtos com índice de TBA menores que $1,0 \mathrm{mg} / \mathrm{kg}$ geralmente não acrescentam sabores e odores residuais de ranço característicos de oxidação lipídica (Olivo \& Shimakomaki, 2001).

Os valores de TBA do peito de frango, encontrados pelas autoras, variaram entre 0,2972 a 0,8875 mg/kg. A análise de determinação do valor de ácido 2tiobarbitúrico (TBA) demonstrou que não houve alteração significativa de sabor e odor na amostra, confirmando a ausência de peróxidos nas miscelas de Folch et al., (1957), Bligh \& Dyer (1959) e Hara \& Radin (1978).

Os valores apresentados na Tabela 8 indicam que o processo de oxidação ocorreu, com acúmulo de peróxidos (4,32 a 4,34 meq $\mathrm{O}_{2} / \mathrm{kg}$ ) na metodologia de Soxhlet (1879) e através da análise de TBA pode-se afirmar que eles não foram quebrados a compostos secundários da oxidação (aldeídos), já que o valor máximo obtido por Pino et al. (2004) não ultrapassou 0,8875 mg/kg. 


\section{CONCLUSÕES}

A metodologia escolhida para a extração da fração lipídica pode afetar a quantidade extraída e a sua qualidade oxidativa. Neste estudo, os solventes utilizados nas extrações e a temperatura influenciaram significativamente a eficiência da extração de acordo com as especificidades e interações nas matrizes analisadas.

O solvente para extração de óleo de um tecido animal ou vegetal deve ser escolhido conforme as características intrínsecas (químicas e físicas) da matriz.

O método de Soxhlet, por ser de execução mais simplificada, pode ser recomendado tanto para amostras de origem animal como vegetal, quando não houver emprego posterior do extrato.

Com base nos resultados deste trabalho, quando as frações lipídicas forem extraídas para uso posterior, recomenda-se a metodologia de Bligh \& Dyer, tanto para amostras de origem vegetal como animal. 


\section{REFERÊNCIAS BIBLIOGRÁFICAS}

AMERICAN OIL CHEMISTS' SOCIETY (AOCS). Official methods and recomended practices. 5.ed. Champaign, 1997. $2 \mathrm{v}$.

ANDERSEN, M.L.; LAURIDSEN, R.K.; SKIBSTED, L.H. Optimising the use of phenolic compounds. Cambridge: CRC Press, 2003. p.315-346: Phytochemical functional foods.

ASSOCIATION OF OFFICIAL ANALYTICAL CHEMISTS (AOAC). Official methods of analysis. 13.ed. Arlington, 2000. 2v.

ATKINS, P.W. Physical chemistry. Oxford: Oxford University Press, 1992. cap.8, p.187-207: Changes of state: the phase rule.

BACCAN, N.; ANDRADE, J.C.; GODINHO, O.E.S.; BARONE, J.S. Química analítica quantitativa elementar. São Paulo: Edgard Blücher, 2001. cap.8, p.191270: Práticas de laboratório.

BLIGH, E.G.; DYER, W.J. A rapid method of total lipid extraction and purification. Canadian Journal of Biochemistry and Physiology, v.37, n.8, p.911-917, 1959.

BUENO, W.A.; DEGRÈVE, L. Manual de laboratório de físico-química. SãoPaulo: Mcgraw-Hill do Brasil, 1980. 282p. 
BURTON, G.; WEBB, A.; INGOLD, K.C. A mild rapid and efficient method of lipid extraction for use in determining vitamin E/lipid ratios. Lipids, v.20, n.1, p.29-39, 1985.

CASTELlAN, G.W. Físico-química. Rio de Janeiro: Livro Técnico S.A., 1973. cap.15, p.342-373: Equilíbrio entre fases condensadas.

CHRISTENSEN, C.M.; KAUFMANN, H.H. Microflora. In: CHRISTENSEN, C.M. Storage of cereal grains and their products. Saint Paul: American Association of Cereal Chemists, 1974. p.158-193.

CHRISTIE, W.W. (Ed.). Lipid analysis. Oxford: Pergamon Press, 1982. cap.3, p.2549: Chromatographic and spectroscopic analysis of lipids: general principles.

CHRISTIE, W.W. Gas chromatography and lipids. Ayr: The Oily Press, 1989. cap.2, p.11-42: Fatty acids and lipids: structures, extraction and fractionation into classes.

CHUNG, O.K. Cereal lipids. In: LORENZ, K.J.; KULP, K. Handbook of cereal science and technology. New York: Marcel Dekker Inc., 1991. cap.13, p.497-553.

COATS, H.B.; KARNOFSKY, G. Solvent extraction. II. The soaking theory of extraction. Journal of American Oil Chemists' Society, v.27, n.2, p.51-53, 1950.

COCKS, L.V.; VAN REDE, C. Laboratory handbook for oil and fat analysis. London: Academic Press, 1966. 419p.

DRUMM, T.D.; SPANIER, A.M. Changes in the content of lipid autoxidation and sulfur-containing compounds in cooked beef during storage. Journal of Agricultural and Food Chemistry, v.39, n.2, p.336-343, 1991. 
ESTADOS UNIDOS. Department of Agriculture. Agricultural Research Service. USDA National Nutrient Database for Standard Reference, http://www.nal.usda.gov/fnic/foodcomp/ (23 July 2004)

FARMER, E.H.; BLOOMFIELD, G.F.; SUNDARALINGAM, A.; SUTTON, D.A. The course and mechanism of autoxidation reaction in olefinic and polyfinic substances, including rubber. Transactions of the Faraday Society, v.38, p.348-356, 1942.

FISHWICK, M.J.; WRIGHT, A.J. Comparison of methods for the extraction of plant lipids. Phytochemistry, v.16, n.10, p.1507-1510, 1977.

FOLCH, J.; LEES, M.; STANLEY, G.H.S. A simple method for the isolation and purification of total lipids from animal tissues. Journal of Biological Chemistry, v.226, n.1, p.497-509, 1957.

GALLIARD, T. Rancidity in cereal products. In: ALLEN, J.C.; HAMILTON, R.J. Rancidity in foods. Glasgow: Blackie Academic \& Professional, 1994. cap.8, p.141-158.

GANDHI, A.P.; JOSHI, K.C.; KRISHNA, J.; PARIBAR, D.C.; SRIVASTAV, P.R.; KAWALKAR, J.; JAIN, S.K.; TRIPATHI, R.N. Studies on alternative solvents for the extraction of oil soybean. International Journal of Food Science and Technology, v.38, n.3, p.369-375, 2003.

GRAY, J.I. Measurement of lipid oxidation: a review. Journal of the American Oil Chemists' Society, v.55, n.6, p.539-546, 1978.

GRAY, J.I.; GOMAA, E.A.; BUCKLEY, D.J. Oxidative quality and shelf life of meats. Meat Science, v.43, p.S111-S113, 1996. Supplement, 1. 
GRAY, D.A.; AUERBACH, R.H.; HILL, S.; WANG, R. et al. Enrichment of oat antioxidant activity by dry milling and sieving. Journal of Cereal Science, v.32, n.1, p.89-98, 2000.

GUNNLAUGSDOLTIR, H.; ACKMAN, R.G. Three extraction methods for determination of lipids in fish meal-evaluation of a hexane/isopropanol method as an alternative to chloroform-based methods. Journal of the Science of Food and Agriculture, v.61, n.2, p.235-240, 1993.

GUNSTONE, F.D.; NORRIS, F.A. Lipids in foods: chemistry, biochemistry and technology. New York: Pergamon Press, 1983. 170p.

GURR, M.I. Role of fats in food and nutrition. London: Elsevier Science Publishers, 1992. cap.4, p.55-73: Extraction and measurement of total fat in foods.

GUTKOSKI, L.C. Composição química. In: GUTKOSKI, L.C.; PEDÓ, I. Aveia: composição química, valor nutricional e processamento. São Paulo: Livraria Varela, 2000. cap.2, p.41-70.

GUTKOSKI, L.C. Processamento de aveia para uso alimentar. Lavoura Arrozeira, v.47, n.1, p.8-15, 1994.

HAMILTON, R.J. The chemistry of rancidity in foods. In: ALLEN, J.C.; HAMILTON, R.J. Rancidity in foods. Glasgow: Blackie Academic \& Professional, 1994. cap.1, p.1-21.

HANSON, S.W.F.; OLLEY, J. Application of the Bligh and Dyer method of lipid extraction to tissue homogenates. Biochemistry Journal, v.89, n.4, p.101-102, 1963. 
HARA, A.; RADIN, N.S. Lipid extraction of tissues with a low-toxicity solvent. Analytical Biochemistry, v.90, n.1, p.420-426, 1978.

HOLE, M.; TAYLOR, K.D.A. Methods of extraction composition and stability of vitamin A and other components in dogfish (Squalus acanthias) liver oil. Food Chemistry, v.55, n.3, p.215-220, 1996.

INSTITUTO ADOLFO LUTZ (IAL). Normas analíticas do Instituto Adolfo Lutz: métodos químicos e físicos para análise de alimentos. 3.ed. São Paulo, 1985. v.1.

INTERNATIONAL UNION OF PURE AND APPLIED CHEMISTRY (IUPAC). Standard methods for the analysis of oils, fats and derivatives. 6.ed. Oxford: Pergamon Press, 1979. 170p.

IVERSON, S.J.; LANG, S.L.C.; COOPER, M.H. Comparison of the Bligh \& Dyer and Folch methods for total lipid determination in a broad range of marine tissue. Lipids, v.36, n.11, p.1283-1287, 2001.

JOHNSON, L.A.; LUSAS, E.W. Comparison of alternative solvents for oil extraction. Journal of American Oil Chemists' Society, v.60, n.2, p.229-242, 1983.

LAUBLI, M.; BRUTTEL, P.A. Determination of the oxidative stability of fats and oils: comparison between the active oxygen method (AOCS Cd 12-57) and the Rancimat method. Journal of the American Oil Chemists' Society, v.63, n.6, p.792-795, 1986.

LUQUE DE CASTRO, M.D.; GARCÍA-AYUSO, L.E. Soxhlet extraction of solid materials: an outdated technique with a promising innovative future. Analytica Chimica Acta, v.369, n.1/2, p.1-10, 1998. 
KATES, M. Techniques of lipidology: isolation, analysis and identification of lipids. London: Elsevier Applied Science, 1972. cap.3, p.347-353: Lipid extraction procedures.

KONING, A.J. de.; EVANS, A.A.; CHRISTINE, H.; PURCELL, C.J.V.; WESSELS, J.P.H. A critical investigation of a number of different methods of lipid determination in fish meal, with particular emphasis on correction required in these determinations. Journal of the Science of Food and Agriculture, v.36, n.3, p.177185, 1985.

KRISHNAMURTY, R.G. Cooking oils, salad oils and salad dressings. In: SWERN, D. Bailey's industrial oil and fat products. 4.ed. New York: Wiley-Interscience, 1982. v.2, p.320-326.

MANIRAKIZA, P.; COVACI, A.; SCHEPENS, P. Comparative study on total lipid determination using Soxhlet, Roese-Gottlieb, Bligh \& Dyer and modified Bligh \& Dyer extraction methods. Journal of Food Composition and Analysis, v.14, n.1, p.93-100, 2001.

MEHLENBACHER, V.C. The analysis of fats and oils. Champaign: Garrard Press, 1960. cap.4, p.188-235: Stability.

MORRISEY, P.A.; SHEEHY, K.G.; KERRY, J.P.; BUCKLEY, D.J. Lipid stability in meat and meat products. Meat Science, v.49, n.1, p.573-586, 1998.

MOTTRAM, D.S. Flavor of meat and meat products. Glasgow: Blackie Academic and Professional, 1994. 210p. 
NELSON, J.G. Isolation and purification of lipids from biological matrices. In: PERKINS, E.G. (Ed.). Analyses of fats, oils and lipoproteins. Champaign: American Oil Chemists’ Society (AOCS), 1991. cap.2, p.20-59.

OLIVO, R.; SHIMOKOMAKI, M. Carnes no caminho da pesquisa. Cocal do Sul: Imprint, 2001. 155p.

PEDÓ, I. Composição química. In: GUTKOSKI, L.C.; PEDÓ, I. (Ed.). Aveia: composição química, valor nutricional e processamento. São Paulo: Varela, 2000. cap.2, p.41-75.

PETERSON, D.M.; EMMONS, C.L.; HIBBS, A.H. Phenolic antioxidants and antioxidant activity in pearling fractions of oat groats. Journal of Cereal Science, v.33, n.1, p.97-103, 2000.

PINO, L.M.; REGITANO-d'ARCE, M.A.B.; SARMENTO, S.B. et al. Estabilidade oxidativa da aveia irradiada (compact disc). In: CONGRESSO BRASILEIRO DE CIÊNCIA E TECNOLOGIA DE ALIMENTOS, 18., Porto Alegre, 2002. Anais. Porto Alegre: SBCTA, 2002.

PINO, L.M.; REGITANO-d'ARCE, M.A.B.; RACANICCI, A.M.C. Estabilidade oxidativa da carne de frangos alimentados com diferentes fontes lipídicas sob congelamento (compact disc). In: CONGRESSO BRASILEIRO DE CIÊNCIA E TECNOLOGIA DE ALIMENTOS, 19., Recife, 2004. Anais. Recife: SBCTA, 2004.

RADIN, N.S. Extraction of tissue lipids with a solvent of low toxicity. In: LOWENSTEIN, J.M. (Ed.). Methods in enzymology. New York: Academic Press, 1981. v.72, parte D, p.5-7. 
RANKEN, M.D. Rancidity in meats. In: ALLEN, J.C.; HAMILTON, R.J. Rancidity in foods. Glasgow: Blackie Academic \& Professional, 1994. cap.11, p.191-202.

REGITANO-d'ARCE, M.A.B. Extração de óleo de girassol com etanol: cinética, ácido clorogênico, fração insaponificável. São Paulo, 1991. 145p. Dissertação (Mestrado) - Universidade de São Paulo.

ROBARDS, K.; KERR, A.F.; PATSALIDES, E. Rancidity and its measurement in edible oils and snack foods: a review. Analyst, v.2, n.113, p.213-224, 1988.

ROSSEL, J.B. Measurement of rancidity. In: ALLEN, J.C.; HAMILTON, R.J. Rancidity in foods. Glasgow: Black Academic and Professional, 1994. cap.2, p.2251.

RUSSEL, J.B. Soluções. In: RUSSEL, J.B. Química geral. São Paulo: Makron Books, 1994. cap.11, p.511-512.

SAHASRABUDHE, M.R. Measurement of lipase activity in single grains of oats (Avena sativa L.). Journal of American Oil Chemists' Society, v.59, n.8, p.354355, 1982.

SAHASRABUDHE, M.R.; SMALLBONE, B.W. Comparative evaluation of solvent extraction methods for the determination of neutral and polar lipids in beef. Journal of the American Oil Chemists' Society, v.60, n.4, p.801-805, 1983.

SCHAFER, K. Accelerated solvent extraction of lipids for determining the fatty acid composition of biological material. Analytica Chimica, v.358, n.1, p.69-77, 1998.

SCHNEIDER, F.H. Fettwissenschaft. Fette Seifen Anstrichmittel, v.80, n.1, p.16-23, 1980. 
SHAHIDI, F. Stability of fats and oils. In: LATIN AMERICAN CONGRESS AND EXHIBIT ON FATS AND OILS PROCESSING, 6., Campinas, 1995. Proceedings. Campinas: Sociedade Brasileira de Óleos e Gorduras, 1995. p.47-54.

SHAHIDI, F.; WANASUNDARA, J.P.D. Extraction and analysis of lipids. In: AKOH, C.C; MIN, D.B. Food lipids: chemistry, nutrition and biotechnology. New York: Marcel Dekker, 1998. cap.5, p.115-135.

SHERWIN, E.R. Oxidation and antioxidants in fat and oil processing. Journal of the American Oil Chemists’ Society, v.55, n.1, p.809-814, 1978.

SIMIC, M.G.; JOVANIC, S.V.; NIKI, E. Mechanisms of lipid oxidative processes and their inhibition. In: St ANGELO, A.J. Lipid oxidation in food. Washington: American Chemical Society, 1992. cap.2, p.14-32.

SMEDES, F. Determination of total lipid using non-chlorinated solvents. The Analyst, v.36, n.124, p.1711-1718, 1999.

SMEDES, F.; ASKLAND, T.K. Revisiting the development of the Bligh and Dyer total lipid determination method. Marine Pollution Bulletin, v.38, n.3, p.193-201, 1999.

SMEDES, F; THOMASEN T.K. Evaluation of the Bligh and Dyer lipid determination method. Marine Pollution Bulletin, v.32, n.8/9, p.681-688, 1996.

SOXHLET, F. Die gewichtsanalytische bestimmung des milchfettes. Polytechnisches Journal, v.232, n.5, p.461-465, 1879.

TARLADGIS, B.G.; WATTS, B.M.; YOUNATHAN, M.T. A distillation method for the quantitative determination of malonaldehyde in rancid foods. Journal of the American Oil Chemists' Society, v.37, n.1, p.44-48, 1960. 
UNDELAND, I.; HÄRRÖD, M.; LINGNERT, H. Comparison between methods using low-toxicity solvents for the extraction of lipids from herring (Clupea harengus). Food Chemistry, v.61, n.3, p.355-365, 1998.

WELCH, R.W. The development of rancidity in husked and naked oats after storage under various conditions. Journal of the Science of Food and Agriculture, v.28, n.3, p.269-274, 1977.

WHITE, E.M. Structure and development of oats. In: WELCH, R.W. The oat crop. London: Chapman \& Hall, 1995. cap.4, p.88-119.

YOUNGS, V.L. Oat lipids. Cereal Chemistry, v.55, n.5, p.591-597, 1978.

YOUNGS, V.L. Protein distribution in the oat kernel. Cereal Chemistry, v.49, n.4, p.407-411, 1972.

YOUNGS, V.L.; PETERSON, D.M.; BROWN, C.M. Oats. Advances in Cereal Science and Technology, v.5, n.1, p.49-105, 1982.

YOUNGS, V.L.; PÜSKÜLCÜ, M.; SMITH, R.R. Oat lipids. I. Composition and distribution of lipids components in two oat cultivars. Cereal Chemistry, v.54, n.4, p.803-812, 1977. 